\title{
NOTE
}

\section{ADMINISTRATION OF THE INTANGIBLE PERSONAL PROPERTY TAX IN PHILADELPHIA *}

\author{
INTRODUCTION
}

Recent trends in state taxation have demonstrated an increasing tendency to exempt intangible personal property. ${ }^{1}$ Pennsylvania recently has joined most of the industrial eastern states in ceasing to obtain revenue from such a source; but, despite constant criticism, ${ }^{2}$ the Commonwealth has retained it for county purposes. ${ }^{3}$ The present tax evolved from a one

* This study was financed by a grant from the Thomas Skelton Harrison Foundation, an agency created by the will of Thomas Skelton Harrison to promote good government in Philadelphia. It was prepared with the cooperation of the Finance Director of the City of Philadelphia and the staff of the Department of Collections, particularly Mr. Romanus Buckley, Deputy Commissioner of Revenue, and Mr. Joseph Tanzola of the Sanctions Division of the Department of Collections. The assistance of the Board of Revision of Taxes and its entire Personal Property Division was very helpful, particularly the constructive criticism of $\mathrm{Mr}$. Wallace Bromley, Chief Personal Property Assessor, and Mr. Samuel Shmukler, Chief Clerk of the Personal Property Division.

1. See Roesken, Trends in the Ad Valorem Taxation of Intangibles, 26 TAxes 639 (1948) ; Roesken, Taxation in the Eastern States, 25 TAXEs 212, 215 (1947). Roesken attributes this tendency to the increasing favor for taxes on income, including the income from intangibles, as well as to the difficulty in the direct assessment of such property because the prevailing high local property tax rates induce much evasion.

A survey of the taxing statutes of all the states with the exception of Pennsylvania, and including Alaska, the District of Columbia, and Hawaii, shows that 33 jurisdictions impose an ad valorem property tax which falls on some form of money, stocks, bonds, credits or other intangibles: Arizona, Arkansas, California, Connecticut, Florida, Georgia, Idaho, Illinois, Indiana, Iowa, Kansas, Kentucky, Louisiana, Maine, Maryland, Michigan, Mississippi, Missouri, Montana, Nebraska, Nevada, New Mexico, North Carolina, North Dakota, Ohio, Oklahoma, Rhode Island, South Carolina, South Dakota, Tennessee, Texas, Virginia, and West Virginia.

The remaining 17 jurisdictions include in their property taxes only tangible personalty, or reach only the income from intangibles: Alabama, Alaska, Colorado, Delaware, District of Columbia, Hawaii, Massachusetts, Minnesota, New Hampshire, New Jersey, New York, Oregon, Utah, Vermont, Washington, Wisconsin, and Wyoming. See TAx Systems 12-154 (C.C.H. 13th ed. 1952 and Supp. 1953); see also Recent Trends in Major State Taxes 1941-1947, at 31-36 ('Tax Foundation Inc. 1948).

2. See, e.g., Clark, The Pennsylvania Personal Property Tax, 83 U. of PA. L. Rev. 875 (1935); Report of Findings AND Recomrmendations on tHe PeNNSYLvania Tax System 23 et seq. (Tax Study Committee Feb. 1949); Pennsyrvania Comimitiee on Continuation of the TAX Study, Report No. 11 c. 16, at 164-82 (1945). The Committee reported: "The statutory provisions, by which both the personal property tax and the corporate-municipal loans taxes are imposed, are compositional atrocities. Both grew to their present state by accretions over the years. Since literally every phase of both provisions has been construed by the courts, there has been some reluctance to modernize their obsolete verbiage. They are, however, verbose, repetitious, and, in some instances, inconsistent." Id. at 171.

3. Pa. Stat. Ann. tit. 72, §4821 et seq. (1950; Supp. 1953). 
mill toll, levied by the state in 1831 on intangible and tangible personalty within the Commonwealth, to an exaction of four mills imposed for county purposes and an equal amount imposed for the benefit of first class school districts. The tax falls generally on intangible capital possessed either by taxable residents ${ }^{4}$ in their own right or by resident fiduciaries who manage the property in the state, as well as on the beneficial interest of any resident in a trust which is managed elsewhere. From $1831^{5}$ to 1913 the tax was assessed and collected by the state, although a portion of the revenue so obtained was turned over to the counties, which aided in its collection. $^{6}$ In $1913^{7}$ the state turned over the entire enforcement of the tax to the counties, and since that date the counties have retained all the revenue obtained from the tax, although from 1935 to 1943 an emergency state act imposed an additional levy on the same class of property. ${ }^{8}$ The first class school districts have been collecting a corresponding amount on the same classes of property since $1947 . .^{\circ}$ In addition, the state has been

4. The term "resident" is defined in the Act to include various forms of business associations. See text following note 85 infra.

5. Pa. Laws 1830-31, No. 111, at 206.

6. For good and fairly complete surveys of the history of the tax, see Schuetz's Estate, 81 Pittsb. Leg. J. (Pa.) 437 (1933); Commonwealth v. Jacob Reed's Sons, 25 Dauph. Co. Rep. (Pa.) 117 (1922). Also see 2 Stradley \& Krekstein, Corporate Taxation and Procedure in Pennsylvania 250-57 (1942); 2 Eastaran, Taxation In Pennsylvania \$720 (1909); 1 CCH Pa. Tax Reporter $\llbracket 24,000$ et seq. (1953); Gilmore, A Comparative Analysis of the Pennsylvania State and County Personal Property Tax Acts and the Administration of EACH 16-19 (M.B.A. Thesis U. of Pa. 1942).

Recent statutory developments which affect the county Act and which are not reported in the above sources include: the exemption of certain public loans and some stock bonus and pension plans by the Act of May 11, 1945, Pa. Laws 1945, No. 179, at 447; a clarifying amendment added by the Act of June 28, 1947, Pa. Laws 1947, No. 432, at 1008, which provided that corporations holding property as mere custodian shall not pay the tax which corporate fiduciaries must pay but which other corporations need not; a provision explaining the method of valuing taxable stock issued by regulated investment companies, added by the Act of January 14, 1952, Pa. Laws 1951-52, No. 573, at 2035, and written into the School Act by the Act of August 26,1953, Pa. Laws 1953, No. 427, at 1463 ; and a minor addition in the Act of August 21,1953, Pa. Laws 1953, No. 367, at 1301, to provide for the reporting of taxable trust funds by bank branches in other counties. See also note 117 infra.

7. Pa. Laws 1913, No. 335, at 507; PA. Stat. AnN. tit. 72, §4821 et seq. (1950; Supp. 1953).

8. Pa. Laws 1935, No. 183 , at 414 , Pa. Stat. Ann. tit. $72, \S 3242$ et seg. (1949). This measure, enacted because of the need for revenue to support the unemployment relief program, was allowed to expire in 1943.

9. In 1947 a temporary tax on such property was imposed for the benefit of what are now termed first class $A$ school districts (those with a population of more than 500,000 and fewer than 1,500,000). Pa. Laws 1947, No. 319, at 733, PA. STAT. ANN. tit. 24, §581.1 et seq. (1950). This was held constitutional in Mikell v. Philadelphia School District, $359 \mathrm{~Pa} .113,58$ A.2d 339 (1948). It was reenacted, as amended, by the Acts of May 12, 1949, Pa. Laws 1949, No. 375, at 1246, and May 29, 1951, Pa. Laws 1951-52, No. 106, at 441. An identical temporary tax for the benefit of all first class school districts (those with a population of over 1,500,000) was imposed by the Act of May 23, 1949, Pa. Laws 1949, No. 509, at 1676, PA. STAT. ANN. tit. 24, $\$ 581.31$ et seq. (1950), and was reenacted as amended and made permanent by the Act of May 10, 1951, Pa. Laws 1951-52, No. 38, at 237. Only the latter act will be cited throughout this Note. Philadelphia is the only first class school district in the state, and Pittsburgh is the only first class A school district. 
obtaining revenue from two sources which would otherwise fall within the scope of a general personal property tax: the principal sum of certain corporate and municipal loans, ${ }^{10}$ and the value of the capital stock of certain corporations. ${ }^{11}$

The amount of revenue obtained from any tax on intangible personal property varies directly with the honesty of the taxable residents, although

Local Governarent Structures in the United States 69 (Bureau of Census, U.S. Department of Commerce 1954). The city of Pittsburgh also imposes a two mill tax on the same property, so that the overall tax rate is ten mills in Pittsburgh, eight mills in Philadelphia, and four mills in all other counties in Pennsylvania.

10. PA. Stat. Ann. tit. 72, $\S 3250-10,3250-11$ a (1949). The corporation is required to withhold the tax from the amount of interest paid by it. This "Corporate Loans Tax" was first enacted in the nineteenth century as a means of collecting the Personal Property Tax, then a state tax, at the source. See Commonwealth v. Jacob Reed's Sons, 25 Dauph. Co. Rep. 117 (1922). The forerunner of this type of $\operatorname{tax}$ was found in $\S 42$ of the Act of April 29, 1844, Pa. Laws 1844, No. 318, at 486 , which imposed a tax on the scrip, bonds or certificates of indebtedness of counties, incorporated cities and districts and boroughs of the Commonwealth. The tax was required to be withheld from the interest payments on such indebtedness, and it became known as the "Municipal Loans Tax." The Act of April 16, 1845, $\mathrm{Pa}$. Laws 1845, No. 348, at 532 extended it by subjecting the public loans and stocks of the state to a tax of one-half mill on every dollar of their value, to be withheld from the interest payments. Section 8 of the Act of April 22, 1846, Pa. Laws 1846 , No. 390 , at 486 , extended this even further to any loans and stocks of private corporations in the Commonwealth whose interest payments were guaranteed by the state, and it also required the withholding of the tax from the interest payments made by the Commonwealth. It was not until $\S 3$ of the Act of April 30, $1864, \mathrm{~Pa}$. Laws 1864, No. 210 , at 218 , however, that collection at the source was extended to private corporations by the requirement that the tax be withheld from the interest payments made by the debtor corporation. This was the "Corporate Loans Tax," which, along with the "Municipal Loans Tax," thereafter existed side by side with the County Personal Property Tax. It was superseded by the Act of May 1, 1868, $\mathrm{Pa}$. Laws 1868, No. 69 , at 108 , repealed in part by $\S 2$ of the Act of March $21,1873, \mathrm{~Pa}$. Laws 1873 , No. 23 , at 46 , wholly repealed by the Act of April 24,1874, $\mathrm{Pa}$. Laws 1874, No. 31, at 68, and reappeared when the state intangibles tax was coordinated with the Corporate and Municipal Loans provisions by the Act of June 7,1879, Pa. Laws 1879, No. 122, at 112. When the enforcement of the intangibles tax was turned over to the counties and all of the taxing provisions were codified, the Municipal and Corporate Loans provisions were made $\S \S 17$ and 18 of the new Act. Pa. Laws 1913, No. 335, at 507. These latter two sections were repealed by the Act of May 18, 1937, $\mathrm{Pa}$. Laws 1937, No. 171, at 633, PA. Stat. ANN. tit. 72, §3242 et seq. (1949). This Act continued the 1935 emergency state tax on intangible property as well as on corporate and municipal loans. The latter provisions were continued in effect even though the other provisions were permitted to expire in 1943, creating the anomalous situation of having the county personal property tax still being collected under the authority of the 1913 act, as amended, while the corporate and municipal loans, falling on many of the same classes of property, is levied and collected by the state under authority of $\S \S 17$ and 18 of the expired state law of $1935, \mathrm{~Pa}$. Laws 1935, No 182 , at 414. See Pennsylvania Comimitee on Continuation of tee Tax Study, supra note 2. Municipal loans were finally exempted from personal property taxes by the Act of May 11, 1945, Pa. Laws 1945, No. 179, at 447. There are a great many similarities and differences between the Personal Property Tax, which is imposed annually on the holder or owners of any taxable property, and the Corporate Loans Tax, which is collected annually only from those debtor corporations which pay interest on their taxable loans and which have a resident treasurer. These similarities and differences have led to a great deal of litigation, some of which will be touched upon in this Note. A thorough comparison and analysis of the relationship between the two taxes would unduly lengthen this report and an excellent treatment of the subject is found in 2 STRADLEY \& KREKSTEIN, op. cit. supra note 6, tit. XII, at 447 et seg. and tit. VL, at 393 et seq. (2d ed. 1952). See also, Pennsyzvania Comamtiee on Continuation of the TAX Study, sipra note 2.

11. PA. Stat. ANN. tit. 72, $\$ 1871$ et seq. (1949; Supp. 1953). 
there are a few methods of checking that honesty. Despite apparent widespread evasion, ${ }^{12}$ Philadelphia now obtains approximately $\$ 2,500,000$ from the levy, and the Philadelphia School District benefits by an approximately equal amount. ${ }^{13}$ Two of the fundamental criteria of an equitable tax are that it should be levied on as broad a base as possible and that it should be collected uniformly and with a minimum of administrative discretion, so as to impose a proportionate share of the burden of the cost of government on the largest possible number of residents obtaining the protection of that government. The possibility of wholesale evasion would violate that principle. The purpose of this Note is to examine and evaluate the assessment, collection and administration of the intangible personal property tax in Philadelphia ${ }^{14}$ in light of these criteria, and to suggest amendments to

12. Of course it is impossible to prove that widespread evasion of the tax exists, but many indications lead to that conclusion. One sign is the lack of knowledge of the existence of the ordinance and of the terms of the tax act. The writer has spoken to many lawyers in Philadelphia who did not know of the tax until a client received notification from the Board of Revision. Even more vivid proof of evasion is the amount of tax attributable to the random returns sent out by the Board to citizens whose names were selected from voting street lists, telephone directories, or other street listings. Many of these returns brought in much unanticipated revenue which would not have been returned otherwise. See note 170 infra. A third sign is the fact that while the emergency tax was being levied by the state on almost identical property, the amount collected exceeded the aggregate collected by the counties, thus indicating that some property which was bearing its burden of the state tax was not being successfully reached by the county officials. See GinMORE, op. cit. supra note 6, at Appendices VII, VIII. Also, the amount of revenue recovered by assessments imposed on the estates of decedents, see text following note 120 infra, is a clear indication that a large amount of property is escaping taxation during the lifetime of its owners.

13. Philadelphia County's personal property tax collections for the years 1938 to 1947 inclusive amounted to $\$ 3,704,900 ; \$ 3,374,100 ; \$ 3,276,360 ; \$ 2,950,500 ; \$ 2,604,500$; $\$ 2,396,700 ; \$ 2,524,360 ; \$ 2,651,000 ; \$ 3,036,700$; and $\$ 2,868,700$. REPORT OF Findings, supra note 2 , at Table 11 . For 1948,1949 and 1950 the figures were: $\$ 2,675,776$; $\$ 2,506,102$; and $\$ 2,509,594$. Tax Collections in Philadelphia, TAX SysTEMs 313 (CCH 13th ed. 1952). For these same latter three years the collections for the school district were: $\$ 2,607,822 ; \$ 2,474,008$; and $\$ 2,434,728$. Ibid. In 1951 and 1952 the city collected $\$ 2,580,378$ and $\$ 2,695,370$ in current personal property taxes and $\$ 55,275$ and $\$ 42,071$ in delinquent personal property taxes. CITY of PhILAdELPHIA 1954 Operating Budget to Accompany Mayor's Budget Message ix (Sept. 22, 1953).

14. The school district tax and the county tax are levied on identical property with only two exceptions: (1) the school tax does not exempt the loans of corporations which pay the corporate loans tax, hence some mortgages, bonds and notes are liable for the four-mill school tax but not for the county tax; and (2) there is a difference in the taxation of equitable interests depending on the residence of the trustee. When there is a single trustee who is a resident of another state, or where there are joint trustees, some of whom are resident in Pennsylvania and some of whom are not, and the property is managed in another state, then both the county and school district taxes are imposed on the resident beneficiary who is entitled to receive all or part of the income. So long as the trust is managed in Pennsylvania, a county tax will be imposed regardless of the county in which the trustee lives. When property is held by joint trustees resident in different counties of the state, the tax is divided among the counties in the proportion of the number of trustees of the property. PA. STAT. ANN. tit. 72, $\$ 4841$ (1950). But if the property is held by a single trustee who is resident in Pennsylvania but not in a first class or first class A school district, or by joint trustees, some of whom are resident in the first class district and some of whom are not and the property is managed in any other school district of the state, the tax is imposed on the resident of the first class district who is entitled to receive all or part of the income. Without this provision in the School District Act, some property might escape taxa- 
make it conform more to the principles of fairness. The legal aspects of the administrative problems will be emphasized, rather than the political and fiscal advisability of taxation or exemption of the various categories of property and persons on which the tax is, or could be, imposed. While a reevaluation of the place of such a tax in the fiscal policy of the state and local governments is significant and advisable today, it is beyond the scope of this Note.

\section{Classes of Property and Persons Made Taxable and Exempted ${ }^{15}$}

The Pennsylvania courts have interpreted nearly every phase of the intangible personal property act, determining not only the classes of property subject to the tax but also the persons liable for its payment. A survey of the tax and a brief discussion of some of the major problems follow.

\section{Classification of Property}

Only the property which falls within one of the classes specifically enumerated in the Act is taxable. ${ }^{18}$ Some forms of intangible interests may

tion, since the property might be held and managed by a trustee in a school district of some other class which does not impose the tax. There is, however, a provision dividing the tax among first class districts in which joint trustees are resident if the property is taxable to them. PA. STAT. ANN. tit. 24, \$581.33(d) (1950).

Furthermore, those officials charged with the assessment and collection of the county tax perform the same task for the school district of Philadelphia. For these reasons, references throughout this report to the Philadelphia County Tax or its enforcement procedure will pertain equally to the enforcement of the first class school district tax; any specific divergencies in the taxing acts or in the enforcement procedure will be noted.

The enforcement of the Emergency State Tax on intangibles, however, differed substantially from that of the County Tax. Since the State Tax is no longer in effect, its enforcement procedures have been largely omitted in this study. However, specific reference will be made to any significant divergencies in the taxing acts themselves. For an excellent comparison of the county and state acts see GILMORE, op. cit. supra note 6. See also 2 STRAdLEY \& KRERSTEIN, op. cit. supra note 6, tit. XI, at 393 et seq.

15. An excellent treatment of the subject of this section can be found in 2 STRADLEY \& KREKSTEIN, op. cit supra note 6, at 258-358. The adequacy of the treatment there leaves little to be added in this report, but the subject matter must be mentioned briefly here so that the following two sections may be completely understood. Some change in emphasis also is necessary for two reasons. Recent developments which do not appear in 2 STRADLEY \& KREKSTEIN are specifically referred to here. Secondly, although the provisions of the County Act were described, Stradley \& Krekstein's text emphasized the provisions of the emergency state levy. The emphasis here is reversed, and the State Act will be noted only when it differs from the County Act. The following section draws very heavily from 2 STRADLEY \& KREKSTEIN in overall organization and in documentation; many portions are short summaries of that text. Accordingly, most of the following subsections refer generally to the section or sections in which Stradley and Krekstein discuss the subject, with specific footnotes to new developments or specially emphasized matters. The lawyer with a specific problem in this area will find it rewarding to start his research with a thorough study of that text. Another valuable reference source is Chapter 24 of 1 CCH PA. TAX REP. (1950), dealing with both the County and State provisions.

16. 2 Stradley \& KRERSTEIN, op. cit. supra note 6, at 312-13. See also Callery's Appeal, $272 \mathrm{~Pa} .255,272,116$ Atl. 222, 228 (1922) (concurring opinion). 
fall within more than one category; some species of property may have the title of one of the enumerated classes but not its incidents, or may possess the incidents without the title. Taxable intangibles can be classed generally as those which represent an ownership interest, such as stocks and interests in trusts, or those representing a creditorship interest, such as mortgages, moneys owing, articles of agreement and accounts, public or private loans, other moneyed capital, or annuity interests. Those representing creditors' interests must constitute monetary claims for a sum certain, and must be both legally enforcible and presently vested. ${ }^{17}$

The following is a list of the categories of property now or formerly taxed and a short description of the nature of each taxable class. ${ }^{18}$

"[A]ll mortgages." 19-A mortgage need not bear interest but must represent a debt to be taxable; it does not fall within this provision of the Act if it is given merely to secure a contingent obligation. When the debt for which the mortgage is security also represents a taxable interest, such as a bond, it has been held that only the debt is taxable. ${ }^{20} \mathrm{~A}$ foreclosure or voluntary conveyance extinguishes the mortgage by terminating the principal debt; but the underlying bond remains taxable if the debtor is still solvent.

" $[A] l l$ moneys owing by solvent debtors, whether by promissory note, or penal or single bill, bond or judgment." 21_To be taxable, the debt must be evidenced by one of the named types of instruments, must be voluntary, and must not be merely contingent. If a bond and mortgage are held by different persons, only the bondholder is taxed. ${ }^{22}$ Judgments are taxed even though they do not bear interest, provided they are valued in money and are entered on a voluntary judgment. Thus, tort judgments, which do not arise voluntarily, and equitable decrees and judgments which cannot be readily valued, such as those granting specific performance, ejectment, replevin, or quieting title, are not taxable. Once judgment is obtained on another form of taxable liability, the liability merges into the judgment and only the latter is taxed.

17. Thus, contingent obligations are not taxed. The debtor's solvency is a requirement only if the taxable interest is evidenced by a promissory note, bill, bond or judgment. See 2 STRADLEY \& KREKSTEIN, op. cit. supra note 6, at 330-32.

18. The first eight categories are expressed in the language appearing in the taxing statutes, PA. STAT. ANN. tit. 72, \$ 4821 (1950) (the County Act), and tit. 24, $\$ 581.32$ (1950) (the School District Act). The remaining three categories represent items that were taxed formerly or others which bear a similarity to taxed items and thereby cause problems of construction. For miscellaneous interests which might pose further problems, see 2 STRADLEY \& KREKSTEIN, op. cit. supra note 6, at 326-30.

19. 2 Stradley \& Krerstein, op. cit supra note 6, at 332-34. See also Commonwealth v. Delaware Division Canal Co., 123 Pa. 594, 624, 16 Atl. 584, 587 (1889); Commonwealth v. Louella Realty Co., 23 Dauph. Co. Rep. 258 (1920).

20. Girard Trust Co. v. Philadelphia, $369 \mathrm{~Pa}$. 499, 87 A.2d 277 (1952), and cases there cited. Also see Commonwealth v. Lotella Realty Co., 23 Dauph. Co. Rep. 258 (1920).

21. 2 Stradley \& Krekstein, op. cit. supra note 6, at 335-39.

22. Girard Trust Co. v. Philadelphia, 369 Pa. 499, 87 A.2d 277 (1952). 
" $[A] l l$ articles of agreeement and accounts bearing interest." 23 Both articles of agreement and accounts must bear interest to be taxed, although the wording of the above phrase in the Act does not make this clear. The most difficult problems under this provision have involved the taxability of the shares of living and dead partners in their partnerships. Generally, such interests are not taxable if they represent the continued participation in the partnership or its profits by either the partner or his estate; they are taxed, however, if they represent a debt of the partnership to the partner or to his estate.

Taxable unincorporated retail stores would seem to be liable for a tax on customers' accounts which bear interest; in practice, very few do require interest. But, if the retail store permits the customer to open a budget account by depositing money in advance and requires him to replenish it as credit purchases deplete the fund, the Department of Revenue ruled that those accounts which paid interest were taxable under the state's emergency personal property tax, unless subject to the Corporate Loans Tax, which would take precedence; the same principle would seem to apply to the County Tax.

If the proceeds of an insurance policy are left with the company to collect interest and then be paid in installments to the beneficiary, they are taxable as an account bearing interest; the 1941 amendment ${ }^{24}$ to the County Tax Act expressly exempted these proceeds, but the provision was never written into the State Act. Interest bearing accounts in financial institutions were exempted by the County Act in $1933,{ }^{25}$ and by the State Act in 1936; ${ }^{26}$ these exemptions were held constitutional. ${ }^{27}$ Such accounts in employee thrift or savings associations were also exempted by the State Act in $1937^{28}$ and by the County Act in 1939.29 Accounts or debit balances owing by customers of bankers or brokers in the usual course of business were exempted by the 1929 Legislature. ${ }^{30}$

"[A]ll public loans whatsoever, except those issued by this Commonwealth or the United States, and except the public loans and obligations of any county, city, borough, towen, township, school district, and incor-

23. 2 Stranley \& Krekstein, op. cit. supra note 6, at 339-44. Note that the Girard Trust Co.'s Case, there cited at page 340,40 Pa. D. \& C. 90 (Philadelphia C.P. 1940), was affirmed after the book was published, in $343 \mathrm{~Pa} .434,23 \mathrm{~A} .2 \mathrm{~d} 454$ (1942). Also, an advancement to a son is not considered an account even though it bears interest. Commonwealth v. Iand Title Bank \& Trust Co., $41 \mathrm{~Pa}$. D. \& C. 318 (Philadelphia C.P. 1941).

24. Pa. Laws 1941, No. 229, at 556. This exemption appeared in the School District Act upon its original enactment. PA. StAT. ANN. tit. 24, 581.32 (1950).

25. Pa. Laws 1933 , No. 40 , at 54. This exemption appeared in the School District Act upon its original enactment. PA. STAT. ANN. tit. 24, §581.32 (1950).

26. Pa. Laws 1936, No. 24, at 51 .

27. Estate of James Donnelly, 113 Pa. Super. 274, 173 Atl. 876 (1934). See also 2 StradLeY \& KRERSTEIN, op. cit. supra note 6 , at 343.

28. Pa. Laws 1937, No. 171, at 633.

29. Pa. Laws 1939, No. 235, at 413. The School District Tax Act contained such an exemption when it was originally enacted.

30. Pa. Laws 1929, No. 449, at 1509. 
porated district of this Commonwealth, and except the bonds and obligations of bodies corporate and politic of this Commonwealth, knozen as municipal authorities." 31_-The exemption of municipal loans dates from 1945.2 Obligations of other states and countries, and their political subdivisions, have been held taxable in the hands of a Pennsylvania resident without violating any constitutional provisions. Obligations of the Commonwealth and its agencies are exempt, as are the obligations of its political subdivisions and their agencies. Congress has also specifically exempted from state taxation the obligations of many federal agencies.

" $[A]$ ll lodns issued by any corporation, association, company, or limited partnership, created or formed under the laws of this Commonwealth or of the United States, or of any other state or government, including cartrust securities and loans secured by bonds or any other form of certificate or evidence of indebtedness, whether the interest be inchuded in the principal of the obligation or payable by the terms thereof, except such loans as are made taxable for State purposes by . . . [Section 17, Pa. Laws, No. 182, at 414 (1935), as reenacted and amended: the Corporate Loans Tax Act, Pa. Stat. Ann. tit. 72, §3250-10 (1949)]." 33_-Those loans which are subject to the Corporate Loans Tax are exempted, consistently with the corresponding provision in that Act. ${ }^{34}$ The provisions of these two taxes overlap; but it was not until $1919^{35}$ that the legislature added a provision to give precedence to the system of collecting the tax at the source.

" $[A]$ ll shares of stock in any bank, corporation, association, company, or limited partnership, created or formed under the laws of this Commonwealth or of the United States, or of any other state or government, except shares of stock in any bank, bank and trust company, national banking association, savings institution, corporation, or limited partnership liable to a tax on its shares or a gross premiums tax, or liable to or relieved from the capital stock or franchise tax for State purposes under the laws of this Commonzealth." 36-In order to avoid the multiple taxation of stock, the Act has, ever since it first assumed its modern form in 1889 , specifically exempted several classes of shares issued by companies which pay various other state corporate taxes. At first under the 1889 Act, ${ }^{37}$ this exemption

31. 2 Stradley \& KREKSTEIN, op. cit. supra note 6, at 347-52. See also $1 \mathrm{CCH}$ PA. TAX REP. $\Uparrow$ 24-015 (1949).

32. Pa. Laws 1945, No. 179, at 447. The School District Act contains a similar exemption. PA. Stat. ANN. tit. 24, \$581.32 (1950).

The State Tax Act exempted those public loans ". . . made taxable for State purposes by section seventeen hereof . ." (which imposed the corporate and municipal loans taxes). PA. Stat. ANN. tit. 72, \$3244 (1949).

33. 2 Stradley \& Krekstein, op. cit. supra note 6, at 352-57.

34. PA. Stat. Ann. tit. 72, § 3250.10 (1949).

35. Pa. Laws 1919, No. 375 , at 955 .

36. 2 Stradley \& Krekstein, op. cit. supra note 6, at 314-26. Also, shares of stock pledged as collateral for bank loans have been ruled taxable under the Emergency State Tax Act. Department of Revenue letter cited in $1 \mathrm{CCH}$ P. TAX REP. f 24-017.19 (1946).

37. Pa. Laws 1889 , No. 332 , at 420 . 
was limited to those shares issued by companies liable to or relieved from the payment of the capital stock tax imposed by $\S 21$ of the 1889 Act; that latter section imposed a graduated stock tax on every corporation incorporated under state law or having capital stock or property employed in this state except banks, savings institutions and foreign insurance companies. Thus, in effect, the shares of all domestic corporations including domestic insurance companies were exempted from personal property tax liability because of their payment of capital stock taxes, and the shares of all banks, savings institutions and foreign insurance companies were also exempted from the personal property tax because they were relieved of liability for the capital stock tax. Since $\$ 24$ of the same Act ${ }^{38}$ imposed a tax of eight mills on the gross premiums of all domestic insurance companies and two per cent on the gross premiums allocable to business done in Pennsylvania by foreign insurance companies, insurance companies did not escape state taxation entirely. The language of this exemption, but not its import, was changed by the 1913 Act. $^{39}$ Then, in $1935, \S 21$ of the 1889 Act was amended to impose a franchise tax on all foreign corporations required to file a report under $\S 20$ of that same Act (which exempted insurance companies) in lieu of the capital stock tax; ${ }^{40}$ but the language of the personal property tax remained unchanged. In that same year the franchise tax paid by foreign corporations to the state was held equivalent to the capital stock tax for this purpose ; ${ }^{41}$ thus most domestic companies (with certain exceptions enumerated in the Act) and foreign companies (except foreign insurance companies) doing business in the Commonwealth were liable for corporate taxes for State purposes and accordingly their shares were exempted from personal property taxation. In Miller's Estate ${ }^{42}$ the court held that, since foreign insurance companies were excepted from the payment of the capital stock tax by $\S 21$ of the 1889 Act, their shares also were not liable to the state personal property tax. In 1937 the State Personal Property Tax Act was amended 43 to eliminate the exemption of shares of corporations relieved from the payment of capital stock taxes; no such provision was adopted by the County Act at this time. In Girard Trust Company's Appeal ${ }^{44}$ the court held that the gross premiums tax paid by foreign insurance companies was also equivalent to the capital stock tax for the purpose of obtaining exemption of their shares from the personal property tax. Then in $1939^{45}$ the County Act was amended to eliminate the

38. Id. $\$ 24$, at 433 .

39. $\mathrm{Pa}$. Laws 1913, No. 335, at 507.

40. Pa. Laws 1935, No. 86, at 184, Pa. Stat. ANn. tit. 72, \$1871(b) (1949). Section 20 of the Act can be found in PA. STAT. ANN. tit. 72, $\$ 1901$ (1949). See Pennsylvania Co.'s Appeal, 40 Pa D. \& C. 489 (Philadelphia C.P. 1940), rev'd, 345 Pa. 130, 27 A.2d 57 (1942).

41. Arrott's Estate, 322 Pa. 367, 185 At1. 697 (1936).

42. $330 \mathrm{~Pa} .477,199$ At1. 148 (1938).

43. Pa. Laws 1937, No. 171, at 633 .

44. $333 \mathrm{~Pa}, 129,3$ A.2d 252 (1938).

45. Pa. Laws 1939, No. 235, at 413. 
"relieved from" provision to bring it in line with the State Act, and both 46 were further amended as a result of the Girard Trust case to limit the exemption specifically to shares of corporations liable for the payment of capital stock or franchise taxes imposed by $\S 21$ of the 1889 Act as amended. This prevented the exemption of any corporation which did not pay either of those taxes, but which did pay the gross premiums tax. These amendments were held unconstitutional by a lower court, ${ }^{47}$ but the Supreme Court of Pennsylvania reversed, ${ }^{48}$ upholding their validity. After the State Act expired, the County Act was amended ${ }^{48}$ to reinstate the provision exempting shares of corporations which had been relieved of the payment of capital stock or franchise taxes, and exemption was again granted to the shares of corporations paying gross premiums taxes or capital stock taxes. Today domestic companies, including insurance companies, are liable for a capital stock tax of five mills, and insurance companies are liable in addition for an eight mill tax on their gross premiums; therefore their shares are exempt from personal property taxation. Foreign insurance companies pay no capital stock or franchise tax, but do pay a two per cent tax on the gross premiums attributable to business done in Pennsylvania, and their shares are also exempted from personal property taxation. Other foreign companies "doing business" in Pennsylvania pay a franchise tax in lieu of the capital stock taxes paid by domestic companies and also pay the two per cent gross premiums tax; their shares are also exempted from personal property taxes in the hands of their holders. Shares of foreign corporations which do not do business in Pennsylvania, and which do not, therefore, pay any corporate taxes to this Commonwealth, are taxable in the hands of their holders..$^{50}$ If a foreign corporation is required to pay any amount of any of the enumerated corporate taxes, its shares are then entirely exempt from the personal property tax ${ }^{51}$ but the foreign corporation cannot voluntarily pay such a corporate tax for which it is not liable merely to relieve its shareholders from the personal property tax on its shares.52

" $[A] l l$ moneys loaned or invested in other states, territories, the District of Columbia, or foreign countries." 53_-This provision is construed narrowly and is largely redundant except insofar as it makes specific the legislative intent not to exempt taxable property merely because it is lent

46. Ibid. (County Tax Act), and Pa. Laws 1939, No. 46, at 76 (State Tax Act).

47. Pennsylvania Co.'s Appeal, 40 Pa. D. \& C. 489 (Philadelphia C.P. 1940).

48. $345 \mathrm{~Pa} .130,27$ A.2d 57 (1942).

49. Pa. Laws 1945, No. 179, at 447.

50. 2 Stradley \& KREKSTETN, op. cit. supra note 6 , at 320 .

51. Dupuy v. Johns, $261 \mathrm{~Pa}$. 40, 104 Atl. 565 (1918); Opperman's Estate, 319 Pa. 466, 179 Atl. 735 (1935). But cf. Commonwealth v. Shenango Furnace Co., 268 $\mathrm{Pa} .283$, 110 At1. 721 (1920). For a further discussion of this subject, see Clark, supra note 2, at 882-83; also see 2 STRADLEY \& KREKSTEIN, op. cit. supra note 6, at 318-19.

52. Callery's Appeal, 272 Pa. 255, 116 Atl. 222 (1922). Accord, McMullin's Estate, $272 \mathrm{~Pa} 284,116$ Atl. 232 (1922). Also see Clark, supra note 2, at 882-83; 2 STRADLEY \& KREKSTETN, op. cit. supra note 6 , at 318-19.

53. 2 StradLEY \& KreKSTEIN, op. cit. supra note 6 , at 356-57. 
or invested in another jurisdiction. Thus, the property probably is taxable even if called by some other name in other jurisdictions.

" $[A] l l$ other moneyed capital owing to individual citizens of the State." ${ }^{54}$-This phrase is to be interpreted as ejusdem generis with the previously enumerated phrases, taxing only property of the same type as that specifically enumerated. It does not make taxable investment trust certificates or the cash surrender value of life insurance policies.

Annuities. ${ }^{55}$ - Formerly, all annuities yielding annually over $\$ 200$ were taxed by both the County and State Acts. In 1937 the State Act was amended 50 to tax the "principal value of all annuities," and in 1939 the County Act was amended ${ }^{57}$ to read: "the principal value of all annuities yielding annually over $\$ 200$." The annuity provision was eliminated entirely from the County Act in $1945 .{ }^{.8}$

Ground Rents and Leasehold Interests in Land. ${ }^{59}$-Ground rents were enumerated as taxable in the 1831 Act, deleted in 1840, and taxed again in 1937 under the Emergency State Tax. This latter provision was invalidated on the ground that a ground rent is really a right in real estate, hence is not taxable as personal property. It was removed from the Act in 1939. Leasehold interests are not enumerated specifically as taxable, and, since they represent an interest in realty, they probably are not taxable. Overdue and unpaid rentals, however, would be taxable if they should fall within a class of taxable creditorship interest such as an account bearing interest, moneys owing by a solvent debtor, or a debt represented by a promissory note.

Bailment Leases. ${ }^{60}$ - The lessee-purchaser clearly owns nothing which could fall within the taxing provisions; he owns merely a lease on the property with an option to purchase at the end of the bailment term. The lessor-seller retains a title interest in the property, which is not taxed under the Act. However, if the purchaser should give a note for the rental installments owed, the note would be taxable to the seller. In actuality, much personal property is sold by installment houses which require the execution of such promissory notes along with the bailment leases, but the installment houses customarily discount the notes immediately with a bank or finance company which is not subject to the personal property tax. ${ }^{01}$

\section{Classification of Taxpayers}

Generally.-Property in any of the enumerated classes is taxable if owned, held or possessed by any resident, whether in his own right, or as

54. Id. at 357-58.

55. Id. at 344-47.

56. $\mathrm{Pa}$. Laws 1937, No. 171 , at 633.

57. Pa. Laws 1939, No. 235, at 413.

58. $\mathrm{Pa}$ Laws $1945, \mathrm{No} .179$, at 447 .

59. 2 STRADLEY \& KRERSTEIN, op. cit. supra note 6 , at 326-27.

60. Id. at 327-28.

61. See text at and following note 163 infra. 
active trustee, agent, attorney-in-fact, or in other such capacity, unless it consists of property received from a nonresident and is held for the benefit of a nonresident. ${ }^{62}$ Since the amendment of the Act in $1941,{ }^{63}$ property held jointly with some other taxable fiduciary or with a nonresident trustee is taxed if held and managed in Pennsylvania. The equitable interest in any enumerated property managed in another state is taxed when legal title is vested in a nonresident fiduciary or in joint fiduciaries, some of whom are nonresident, and when the resident beneficiary is entitled to receive all or any part of the income therefrom. ${ }^{64}$ An estate of a decedent is taxable in the county of his domicile at death, regardless of the place of residence of the administrator or executor. ${ }^{65}$ The trustee's place of residence is considered to be his home, not his office. Only fiduciaries with active duties are taxed by the Act; if the fiduciary is inactive, then the property is taxed to the beneficiary. In order to be considered active, affirmative duties are required, and title must be in the trustee's name to prevent his being a mere agent or bailee.

Trustees and Beneficiaries. ${ }^{66}$-Generally, resident trustees are taxable if they have active duties. A tax levied on property held for nonresidents would be constitutional, since based on control over the resident trustee; but since 1929 no tax is levied if the property has been received from a nonresident (whether he be the settlor or merely a contributor of property to the trust) for the benefit of a nonresident. This 1929 amendment to the County Act (the State Act as passed in 1935 also contained such a provision) was intended to encourage out-of-state trusts. If both the beneficiary and the trustee of a locally-held trust reside in this Commonwealth, the

62. "All personal property of the classes hereinafter enumerated, owned, held or possessed by any resident . . whether such personal property be owned, held, or possessed by such resident in his, her, their, or its own right, or as active trustee, agent, attorney-in-fact, or in any other capacity, or by any resident as trustee, agent or attorney-in-fact, jointly with one or more trustees, agents or attorney-in-fact domiciled in another state, where such personal property is held and managed in this Commonwealth, except as executor or administrator of the estate of a nonresident decedent, and except as trustee for a resident or nonresident religious, charitable or educational organization, no part of the net earnings of which inures to the benefit of any private stockholder or individual for the use, benefit, or advantage of any other person, copartnership, unincorporated association, company, joint-stock company or association, limited partnership, bank, or corporation .. . And provided further, That the provisions of this section shall not apply to personal property of the class hereinabove enumerated, received or acquired with proceeds of money or property received from any person or persons, copartnership, or unincorporated association or company, nonresident in or not located within this Commonwealth. . "PA. Stat. ANN. tit. 72, \$4821 (1950); tit. 24, §581.31 (1950); tit. 72, §3242 (1949).

See Guthrie v. Pittsburgh C.C. \& St. L. Ry., 158 Pa. 433, 27 Atl. 1052 (1893); see also $1 \mathrm{CCH}$ PA. TAX ReP. $\| 24-011.12$ (1946).

63. Pa. Laws 1941, No. 229, at 556.

64. PA. Stat. Ann. tit. 72, §4821 (1950). The School Tax Act, tit. 24, §581.32 (1950), and State Tax Act, tit. 72, §3244 (1949), contain similar provisions.

65. See text following note 72 infra. See also 2 Stradley \& Krekstein, op. cit. supra note 6 , at 296.

66. 2 Stradley \& KreKSTEIN, op. cit. supra note 6, at 276-82. For problems arising from various special forms of trust arrangements such as voting trusts, trusts for bondholders, etc., see id. at 282-87. 
trustee is taxed, not the beneficiary, regardless of the counties in which they reside. Prior to 1936 under the State Law and 1939 under the County Tax Act, the beneficial interest of a foreign-held trust was not taxed at all. Now it is taxed if legal title is in the nonresident and the resident beneficiary is entitled to all or part of the income. If the beneficiary is entitled to the life income only, the Act provides a means of measuring the tax, ${ }^{87}$ and tables have been developed to reduce the value of the taxable property in order to tax only the expectancy, rather than the entire value of the property in the trust. ${ }^{68}$

Principal and Agent. ${ }^{60}$-If the principal is a nonresident, the agent must be active to some degree in order to give a taxable situs in Pennsylvania, since the "business situs" doctrine apparently is not applied by the Pennsylvania courts. Stocks registered in a street name are taxable to the owner, not to the broker, ${ }^{70}$ and stocks purchased on margin from a broker in another state are taxable to the holder here. ${ }^{71}$

Executor and Administrator. ${ }^{2}$-During administration, the property is considered to be in the custody of the probate court with jurisdiction over the fiduciary, and is taxed in that county. Where the estate is nonresident and the personal representative is resident in Pennsylvania, no tax is collected under the terms of the Act; but where the estate is resident and the personal representative is not, the property in the estate is taxable, and the return must be filed in the county in which the personal representative qualified. On distribution, the property is taxable to the distributees. A mortgage held by a resident decedent's estate secured by real estate in a foreign jurisdiction is not exempt, even though the foreign jurisdiction has taxed the realty. ${ }^{\text {T8 }}$

Guardian and Ward. ${ }^{74}$-The domicile of the ward should govern the questions of residence in the state and of which county is entitled to the tax; however, the Act does not so specify and case law leaves some doubt.

67. "The value of the equitable interest in any personal property, made" subject to tax by this section, shall be measured by ascertaining the value of the personal property in which such resident has the sole equitable interest, or in case of divided equitable interests in the same property, then by ascertaining such part of the value of the whole such personal property as represents the equitable interest of such resident therein." PA. STAT. ANN. tit. $72, \S 4821$ (1950); tit. 24, $\$ 581.31$ (1950); tit. $72, \S 3244$ (1949).

68. See 2 STRAdLEY \& KRERSTEIN, op. cit. supra note 6 , at 385-93, for the process of valuation of part interests; see also $1 \mathrm{CCH}$ PA. TAX REP. $\llbracket 24-011.22$ (1946).

69. 2 Stradley \& Krekstein, op. cit. supra note 6, at 293-96.

70. Bishop's Estate, 33 Pa. D. \& C. 139 (Philadelphia Orphans' Ct. 1938).

71. Commonwealth v. Lott, $348 \mathrm{~Pa}$. 442, 35 A.2d 263 (1944). As to common and commingled trust funds, pension and retirement and business trusts, see 2 STRAdLEY \& KrERSTEIN, $o p$. cit. silpra note 6 , at 284-86.

72. 2 Stradley \& KREKSTEIN, op. cit. supra note 6, at 296.

73. Steele Estate, 68 Montg. Co. Law Rep'r (Pa.) 49 (1951) ; National Bank of Germantown and Trust Company's Appeal, 156 Pa. Super. 650, 41 A.2d 412 (1945).

74. 2 Stradley \& KreksterN, op. cit. sipra note 6, at 296-98. 
Bailor and Bailee. ${ }^{75}$-The owner of the property is taxed; the mere possession or custody of a bailee is not enough to make the property taxable to him.

Court-Appointed Receivers or Trustees. ${ }^{76}$-No tax would be imposed on a receiver, since the corporation for which he is receiver is liable for other corporate taxes and would be exempt from personal property taxation, and also since the trustee is mere custodian for the corporation and its creditors. Likewise, neither a trustee in bankruptcy nor a corporation in reorganization would have to pay the tax.77

Exempted Representatives. ${ }^{78}$-Certain taxable residents holding property in a representative capacity are exempted by statute and case law in order to avoid the danger of double taxation or to avoid encroachment upon federal powers, or simply because of a strong public policy, such as that favoring charities.

Joint Holders of Property. ${ }^{79}$ - If the property is held in his own right, each holder would be taxed on his own interest. Thus, tenants in common would be taxable for their proportionate share of the property; joint tenants or tenants by the entireties would be taxable for equal interests in the property (although theoretically this is inaccurate, since the value of the present right of possibility of survivorship possessed by each joint tenant should be determined by the application of actuarial tables governed by the age of each holder); and each holder of successive legal interests would be taxable on his own interest.

When the property is held jointly in a representative capacity, the problem is more complex. Co-executors must file a single return in the county of domicile of the decedent at his death. Joint guardians of a ward file one return where the ward is domiciled. Prior to 1941, when property was managed in another state and was held by co-trustees some of whom were nonresident in Pennsylvania, it was held not taxable by Pennsylvania. ${ }^{80}$ There was also dictum to the effect that, so long as there were some nonresident trustees, no tax could be collected even though the prop-

75. Id. at 299.

76. Id. at 299-302.

77. The Act of June 19, 1939, added the provision:

". . . nor to personal property held in the commercial department and owned in its own right by a banking institution, savings institution, or trust company, in liquidation by a receiver, trustee, or other fiduciary. . . " $\mathrm{Pa}$. Laws 1939, No. 235, at 413 .

Pa. Laws 1941, No. 228, at 552 added:

". . . nor to personal property formerly held by a banking institution in its own right, but assigned by it to one or more trustees for liquidation and payment to the creditors. . . ."

These provisions were added to the State Tax Act by the Act of July 11, $1941, \mathrm{~Pa}$. Laws 1941, No. 145, at 361. The School Tax Act contained such a provision when originally enacted. PA. Stat. ANN. tit. 24, §581.31 (1950).

78. 2 Stradley \& KREKSTEIN, op. cit. supra note 6, at 302-06.

79. Id. at 306-12.

80. Dorrance's Estate, 333 Pa. 162, 3 A.2d 682 (1939). Cf. Griscom's Estate, 333 Pa. 186, 3 A.2d 693 (1939). 
erty was managed in Pennsylvania. ${ }^{81}$ The 194182 legislature made the trust domicile-the place of administering the trust-the determinative factor, and this remains true today. When property is held by co-trustees, all of whom are resident in Pennsylvania but in different counties, the tax is split proportionately among the counties involved. The provision to this effect was enacted in $1939^{83}$ to overrule a decision holding that the county in which the trust was managed was entitled to the entire tax. ${ }^{84}$

Persons Holding in Their Own Right. ${ }^{85}$ - The tax is imposed on property owned, held or possessed by any resident, which is defined in the Act to mean:

“. . . any person, persons, copartnership, or unincorporated association, company, resident, located, or liable to taxation within this Commonwealth, or by any joint-stock company or association, limited partnership, bank or corporation whatsoever, formed, erected or incorporated by, under, or in pursuance of any law of the Commonwealth or of the United States, or of any other state or government, and liable to taxation within this Commonwealth . . . except as trustee for a resident or nonresident religious, charitable or educational organization, no part of the net earnings of which inures to the benefit of any private stockholder or individual for the use, benefit or advantage of any other person, copartnership, unincorporated association, company, joint-stock company or association, limited partnership, bank or corporation. . . ." 86

The word "resident" as used in the Act means "domiciled." 87 Section 2 of the Act ${ }^{88}$ specifies the county in which returns must be filed by corporations and other business organizations liable to the tax.

Exempted Persons and Organizations.-The first section of the Act provides specific exemptions for several forms of business associations:

81. Dorrance's Estate, 333 Pa. 162, 170, 3 A.2d 682, 686 (1939); id. at 176, 3 A.2d at 688 (dissenting opinion).

82. Pa. Laws 1941, No. 227, at 548 (County Tax Act) ; Pa. Laws 1941, No. 145, at 361 (State Tax Act).

83. Pa. Laws 1939, No. 235, at 413, PA. Star. ANn. tit. 72, §4841 (1950). Cf. the School Tax Act, PA. Stat. ANn. tit. 24, §581.33(d) (1950), which makes provision for dividing the tax between the school districts imposing such a tax in a similar manner. No such provision appeared in the State Tax Act, since if the property was managed in Pennsylvania, the full amount was taxable thereunder by the state regardless of the county in which any trustee resided.

84. Griscom's Estate, 333 Pa. 186, 3 A.2d 693 (1939). The 1939 Act was held constitutional in Fidelity-Philadelphia Trust Co.'s Appeal, $337 \mathrm{~Pa} .34,10$ A.2d 547 (1940).

85. See 2 STRAdLEY \& KREKSTEIN, op. cit. supra note 6 , at 260-75 for an enumeration of the problems peculiar to the various forms of business organizations which are taxed by the Act.

86. PA. Stat. Ann. tit. 72, § 4821 (1950).

87. Guthrie v. Pittsburgh, C.C. \& St. L. Ry., 158 Pa. 433, 27 At1. 1052 (1893) ; Reynard's Appeal, 20 Pa. Dist. 932 (1909), $38 \mathrm{~Pa}$. Co. Ct. 362 (Wayne County 1911). Also see Dorrance's Estate, 309 Pa. 151, 163 Atl. 303 (1932) (arising under the Inheritance Tax Act).

88. PA. Stat. ANn. tit. 72, §4841 (1950). 
“. . . the provisions of this act shall not apply to building and loan associations, . . . fire companies, firemen's relief associations, life casualty or fire insurance corporations having no capital stock, secret and beneficial societies, labor unions and labor union relief associations, and all beneficial organizations paying sick or death benefits, or either or both, from funds received from voluntary contributions or assessments upon members of such associations, societies, or unions: And provided further, That corporations, limited partnerships, and jointstock associations liable to tax on their shares or the aforesaid capital stock or franchise tax for State purposes, shall not be required to make any report or pay any further tax, under this section, on the mortgages, bonds, and other securities owned by them in their own right; . . . nor shall the provisions of this section apply to personal property held for the use, benefit or advantage of any resident who shall have in each of the ten preceding calendar years given or contributed all of his net income to any corporation organized or operated exclusively for religious, charitable, scientific, literary, or educational purposes." 89

The Act also exempts bank notes or notes discounted or negotiated by banks, banking institutions, savings institutions or trust companies; loans, shares or other securities held by bankers solely for trading purposes; accounts or debit balances owing by customers of bankers or brokers in the usual course of their businesses; interest bearing accounts in banks, savings institutions, employes' thrift or savings associations; and personal property held in the commercial department and owned in its own right by a financial institution in liquidation or assigned by such an institution to a trustee for liquidation. ${ }^{90}$ Furthermore, domestic banks, title insurance companies and trust companies pay the shares tax, and thus are exempt from personal property taxes; ${ }^{91}$ foreign financial institutions are expressly exempted from the franchise tax and would thus seem to be liable for the personal property $\operatorname{tax}$.

\section{Mechanics of Assessment and Collection}

Tax liability should be determinable with a minimum of administrative discretion in order to preclude tax administrators from usurping the legislative prerogative. ${ }^{92}$ The tax on intangibles is a notorious violator

89. PA. Stat. ANN. tit. 72, §4821 (1950).

90. Ibid. The exemption of loans held by bankers for trading purposes was added by the Act of May 2, 1929, Pa. Laws 1929, No. 449, at 1509; the exemption of interest-bearing accounts in banks, by the Act of April 21, 1933, Pa. Laws 1933, No. 40, at 54; and the exemption of personal property assigned to a trustee for liquidation by such an institution, by the Act of July 29, 1941, Pa Laws 1941, No. 228, at 552. See Commonwealth v. McKean County, $200 \mathrm{~Pa}$. 383, 49 Atl. 982 (1901); also see Clark, supra note 2, at 883-86.

91. PA. Star. ANn. tit. 72, §4821 (1950); tit. 24, \$581.32 (1950); tit. 72, $\$ 3244$ (1949). A shares tax on banks, title insurance, and trust companies is imposed by PA. Stat. ANN. tit. 72, §\$1911, 1991 (1949).

92. REPORT of Findings, op. cit. supra note 2 at 2. 
of this principle. It also provides an unstable source of county revenue, ${ }^{93}$ and for the most part either is not enforced at all, or, if enforced, is not assessed and collected uniformly. ${ }^{94}$ However, Philadelphia is one of the counties which does make an attempt to enforce the Act, and the following is an outline of the administrative difficulties, heightened by avoidable inefficiency, facing such an attempt.

\section{Assessment.-The Act provides that annually the Board of Revision} of Taxes ${ }^{95}$ shall furnish blanks to assessors, who shall send a copy to taxable persons. ${ }^{96}$ On this blank the taxable is required to return annually the aggregate amount of all classes of taxable personal property held either in his own right or for other persons. The return must be certified and should contain on the reverse side the value of all intangible property owned or possessed by the resident, whether believed to be taxable or not, as of the tax date, ${ }^{97}$ which has been fixed as January 1 of each year. Usually in the last week of December the Board of Revision mails blanks to every taxable who filed a return for the previous year, to anyone the Board has reason to suspect owned or possessed intangibles during the

93. Id. at 23; Iocal Government Finances in Pennsylvania 19 (Dep't Internal Affairs 1945); GILMORE, op. cit. supra note 6, particularly at 2, 60-64.

94. Ibid.

95. In Philadelphia the tax assessment and revision body is the Board of Revision of Taxes, which is charged with the assessment of both real estate and personal property taxes. The Board's Personal Property Division is composed of a chief personal property assessor, and one personal property assessor and several assistant assessors for each of the city's eight districts. There is also a Chief Clerk of the Personal Property Division, who is in charge of administrative details of the office and who acts in effect as the assistant to the Chief Assessor. Appeals from assessments made by the Personal Property Division are taken to the seven member Board of Revision. For general provisions concerning the Board and its functions, see Pa. Stat. ANn. tit. 53, $\$ 4791-815$ (1931; Supp. 1953). The Board is also charged with the assessment of the personal property tax levied by the Philadelphia School District. Pa. Stat. ANN. tit. 24, \$581.31 et seq. (1950). Throughout the remainder of this Note the term "Board" will refer to the Personal Property Division, unless otherwise specified.

In 1951 the voters of Philadelphia adopted a Home-Rule Charter and also approved consolidation of the city and the county. In 1953 the state legislature passed a bill providing for the implementation of this consolidation, but exempted four of the former county offices (including the Board of Revision) from the merger provisions. $\mathrm{Pa}$ Laws 1953, No. 433, at 1476. See Philadelphia Inquirer, July 24, 1953 , p. 1, col. 1. Involved court litigation has followed, culminating in a 4-3 decision of the state's supreme court ruling the exemption of the four offices unconstitutional. Clark v. Meade, $377 \mathrm{~Pa}$. 150, 104 A.2d 465 (1954). The Philadelphia City Council then passed an ordinance abolishing the Board of Revision and turning over its functions to a chief assessor under the Department of Finance. Philadelphia Evening Bulletin, August 13, 1954, p. 3, col. 1. But the legality of this ordinance and its implementation are now being litigated. As yet no major changes have been made in personnel or functions. See also note 126 infra.

For the procedure of assessment and collection followed by the state when it levied the emergency tax on personal property from 1935 to 1943 , see Grware, op. cit. silpra note 6 , at 24-41.

96. PA. Stat. AnN. tit. 72, \$4841 (Supp. 1953).

97. PA. Stat. Ann. tit. 72, $\$ 4843.2$ (1950). The School District Act contains a similar provision, PA. Stat. AnN. tit. 24, §581.34 (1950; Supp. 1953). The Board customarily prints on the returns the date of January 1 . 
year, and to a random sample of residents chosen from the telephone book or voting registration street lists. ${ }^{98}$ The returns are due February 15 of each year ${ }^{99}$ and a wilful failure to file is declared a misdemeanor punishable by a fine of not more than $\$ 500$ or imprisonment for not more than six months or both. ${ }^{100}$ Although the Act does not so require, it is advisable for a resident who does not possess taxable property to write "None" across the return and mail it to the Board, and for a nonresident who was formerly on the Board's books to sign the nonresident affidavit provided on the back of the return and mail it to the Board. These precautions should be taken because the Board will send an "Estimated Assessment of Personal Property Subject to Taxation" to every taxable who has not submitted his return by February 18 , as well as to those taxables who have returned less property than the Board has reason to believe they possessed, or who have filed an incorrect return. This estimate explains in what manner the taxpayer has failed to comply with the Act and that the listed estimated assessment has been made by the Board with a twelve per cent penalty added, which aggregate amounts shall be the basis for taxation for county and school purposes. ${ }^{101}$ The notice also informs the taxable

98. The practice of sending returns to a random sample of residents is of recent origin. The Board calls these returns "flyers." In December, 1952, The Board sent out 33,098 regular returns, 29,054 "flyers" and 498 others. In December, 1953, it sent out 32,836 regular returns, 45,878 "flyers" and 469 others. The sample is not completely random since the names are drawn from street lists concentrated in the wealthy areas of the city, where the residents are more likely to own taxable property.

99. PA. Star. Ann. tit. 72, \$4843.1(a) (1950). The School District Act has a similar provision. PA. Stat. ANN. tit. 24, $\$ 581.33$ (a) (1950; Supp. 1953). For the provisions concerning payment of the tax, see text at notes 113,114 and notes 113,114 infra.

100. PA. Stat. AnN. tit. 72, $\$ 4843.1$ (d) (1950). The similar School District Act provision can be found in PA. STAr. ANN. tit. 24, §581.45(c) (1950; Supp. 1953). The State tax contained no such provision.

101. PA. Stat. Ann. tit. 72, $\$ 4844$ (1950). The similar School District Act provision can be found in PA. STAT. ANN. tit. 24, \$581.37(a) (1950; Supp. 1953).

The twelve per cent penalty can be imposed only in the current taxable year in the estimated return; the legislature did not intend this penalty to apply to assessments made after the year in which the tax should have been assessed and paid. Leopold Tax Assessment Case, 118 Pa. Super. 158, 179 Atl. 904 (1935). See also 2 STRADLEX \& KREKSTETN, op. cit. sitpra note 6 , at 401.

In practice, the Board customarily makes its estimate for fifty per cent more than the amount of property listed by the taxpayer on a former return or, if no former return is available, for fifty per cent more than the amount of property which the taxpayer is believed to have possessed; then the twelve per cent penalty is added. The Board believes that if the figure thus set is sufficiently high and exceeds the amount of property actually possessed by the resident, he will generally invoke the provisions for appeal, and that in the course of the succeeding investigation the Board will be able to obtain more accurate information as to the actual amount of property he possessed. If, on the other hand, the taxpayer fails to appeal, that is a good indication that he possessed even more property than estimated, and that succeeding estimates for subsequent years, in constantly increasing amounts, will eventually bracket the amount of taxable property owned by the taxpayer.

In Appeal of Van Nort, $121 \mathrm{~Pa} .118,15$ Atl. 473 (1888), the court held that an estimated assessment based on mortgages which had actually been satisfied was within the power of the Board acting on its best information, as required by the Act at that time; taxpayer's failure to appeal precluded him from enjoining the collection of this tax. In Philadelphia v. Kolb, $288 \mathrm{~Pa}$. 359, 136 At1. 239 (1927), 
that if he is dissatisfied with the above assessments he may, on or before the appeal day, February 25, present reasons supported by oath or affirmation for the failure to file a correct return and may request the Board to accept his own return in place of the estimate. ${ }^{102}$ In the case of a false return, the Board may not cancel the twelve per cent penalty, and the estimated return will be final except where a correct return reveals a higher assessed value. ${ }^{103}$ Shortly thereafter the tax books are closed. If any further taxable property is discovered, the Board may make a corresponding "additional assess-

the Board added fifty per cent to each year's assessment and returned the total as the assessment for the following year. The city sued to collect the tax and its demurrer to the taxpayer's defense that the Board did not act on its best information was upheld on the ground that if the taxpayer, who admitted liability but merely questioned the amount, thought the estimate to be excessive, it was his duty to bring the matter before the Board by appealing. But in Allegheny County Personal Property Tax Assessment Cases, $349 \mathrm{~Pa} .651,37$ A.2d 498 (1944), the taxpayer filed a return based on his opinion of the valuation of the property which he possessed; the Board made a reassessment to raise the valuation to the amount recorded on the New York curb market. It was held that under the statute the Board has no power to reassess unless the returns are false or incomplete; here they were not, since the taxpayer's opinion of their value was in good faith. The words "inaccurate" and "incorrect," which appear in the present statute, would seem to permit a reassessment based on revaluation.

An assessment may be made by the Board at any time within five years after any property owned, held or possessed by any resident should have been returned for taxation, even though the resident may have paid a tax assessed on the basis of returns previously filed, and even though the Board may have made previous assessments against the resident. PA. STAT. ANN. tit. 72, \& 4844 (1950). This provision for assessment within five years was added in 1927 after the court had held in Schmuck v. Hartman, $222 \mathrm{~Pa} .190,70 \mathrm{Atl} .1091$ (1908), that under the 1889 act no provision existed for assessment for any year prior to the year in which the assessment was being made. Section 5 of the 1927 amendment provided that an assessment could be made for "any former years, not exceeding five," Pa. Laws 1927 , No. 476 , at 985 ; this was held to mean the five-year period immediately preceding the year of assessment. Erie County v. Sterling, $319 \mathrm{~Pa} .568,181$ At1. 505 (1935).

102. "Any resident, against whom an assessment is made, may petition the board of revision of taxes . . . for a reassessment. Notice of an intention to file such a petition, or to appear and be heard, shall be given to the board of revision of taxes... within thirty (30) days after notice of such assessment is given or sent by the board of revision . . to the taxpayers, as provided in this act. . . ." Pa. Stat. ANN. tit. 72, $\$ 4844.1$ (1950). The Act also provides for the manner of hearing the appeal and for the right to a subsequent appeal to the court of common pleas. However, the setting of an appeal date is not very significant to the taxpayer since, in 1951, a section was added to the Act relating to the functions of the Board of Revision, which permits appeals after the thirty-day date indicated above: "With respect to the assessment of personal property, it shall be the duty of the board to hear appeals, whenever it is in session, at any time subsequent to the time prescribed for appeals and previous to payment of the tax and to make such revision thereof as shall appear to the board to be just and reasonable, in the same manner as it might have done at the time prescribed for appeals from personal property assessments. No such appeal shall be heard unless the person aggrieved by any assessment shall have given due notice thereof to the personal property assessor of the proper district." PA. STAt. ANN. tit. 53, \$ 4805.14a (Supp. 1953), added by the Act of July 9, 1951, Pa. Laws 1951-52, No. 236, at 1083. While this permits appeals later than the thirty-day limit formerly provided, it still requires notice to the assessor of the intention to file an appeal. Yet, as indicated in a memorandum to Revenue Commissioner Forde from Deputy Commissioner Buckley, dated May 14, 1953; ". - in several cases taxes listed as delinquent were wiped out by a late appeal to the Board or to a Board member." Repeal of this provision and reinstatement of the former thirty-day limit was accordingly recommended.

103. Pa. Stat. Ann. tit. 72, §4844 (1950). 
ment"; it must give notice to the taxable who may appeal in the same manner as an original assessment. ${ }^{104}$ If an appeal is successful, either to the Board or to the courts, an "allowance" is granted, thus correcting the amount of the assessment shown on the books. The Board of Revision computes the tax after approving the return or substituting the estimate along with any "adds" or "allowances." 105 The tax is computed by multiplying by four mills both the aggregate amount of property taxable for county purposes and the aggregate amount of property taxable for school purposes.

The key to the unnecessarily awkward assessment procedure lies in the records kept by the Board of Revision. The records were first kept by ward and district because the original assessment procedure required the assessor to visit every house within his district and to compile and value the personal property owned by each resident. Although the present method of tax collection has eliminated the need for this recording system, it remains unchanged. Thus, because shifts in the residences of taxables cannot be traced easily, much property escapes taxation as the mobility of population increases. Annually when a return is received from a taxable, his name, address, former address if any, and the amount of property he returns taxable for county and school purposes are entered in four separate records: the "Assessor's Book," in which the computation of the tax is made; the "Duplicate," which is sent to the Department of Collections to form the basis of the collection procedure; the "Triplicate," which is sent to the City Controller for audit; and the "Blotter," which is retained by the Board for checking the accuracy of the returns and computing the amount of property which the taxable can be expected to return each year. Every page of the Blotter is divided into several horizontal rows of six blocks each. The first block on each row contains the address and the name of a taxable resident. Any former filing address is noted along with the page number of the Blotter on which his former information is recorded.100 Also listed is information obtained by the Board as to the amount of taxable property possessed by the taxable. ${ }^{107}$ The remaining five blocks contain the information as to the assessment of the tax for each of five years.

104. PA. Stat. ANw. tit. $72, \S 4845$ (1950). No such provision appears in the School District Act, other than that mentioned in the text at note 101 supra. This additional assessment is referred to by the Board as an "add," and will be so termed throughout the remainder of this Note.

105. The expired State tax provided that the resident should compute and pay his tax along with the filing of the return. PA. STAT. ANN. tit. 72, 33245 (d) (1949).

106. The tax return directs the taxable to note any former filing addresses. The notation of the new address is also made in the Blotter page containing the information received from the old address.

107. Formerly such information was noted in the Blotter in pencil, and thus anyone who might acquire access to the books could easily erase or change the records. Although no evidence of intentional falsification was found during the course of this study, the practice clearly creates a situation that would not be tolerated in private industry where comparable amounts of money would be involved. In addition, the difficulty in reading faded pencil notations and the danger of accidental erasures and smudges would alone warrant a change in the system. The present Chief Clerk has taken some steps to correct this situation. 
Assume that a taxable makes a return for 1954 listing property valued at $\$ 10,000$ for both county and school purposes; this information will be listed opposite his name in the block for the appropriate year. But assume also that the first block shows that the taxable actually possessed property valued at $\$ 50,000$. This forms the basis for an estimate which is sent to the taxpayer. All such further action, i.e., estimates, adds, or allowances, is noted in the appropriate block of the Blotter which thus will give a complete picture of each resident's tax assessment status for five years. ${ }^{108}$ When the five years have elapsed, that volume of the Blotter is filed and a new one is prepared for the next five years.

The Blotter is divided into several segments, each bound by hard covers, and every page is removable. Within each binder every page is filed by address, with an index in the front to enable the searcher to find the page on which the residents of each street are listed. Although it would seem that there should be a row for each resident of every house in the city, there are rows and entries only for those people who have

108. For example, a sample page of the Blotter appears as follows (hypothetical names and addresses used):

\begin{tabular}{|c|c|c|c|c|c|c|c|}
\hline & \multicolumn{3}{|c|}{ SARIPLE STREet-West StDe } & \multirow[b]{2}{*}{1953} & \multirow[b]{2}{*}{1954} \\
\hline & & & 1950 & 1951 & 1952 & & \\
\hline \multirow{2}{*}{\multicolumn{2}{|c|}{$\begin{array}{l}1000 \text { Sample St. } \\
\text { Jones, John } \\
M 1000 \\
J N 500\end{array}$}} & & $\mathrm{C}$ & \multirow{2}{*}{$\mathrm{C}^{1500}$} & \multirow{2}{*}{$\begin{array}{l}\mathrm{C}_{2520 E} \\
\mathrm{~s}^{252}\end{array}$} & \multirow{2}{*}{$\mathrm{C}_{1500}$} & \multirow{2}{*}{$\mathrm{C}_{1500}$} \\
\hline & & & $S$ & & & & \\
\hline \multicolumn{2}{|c|}{$\begin{array}{l}1006 \text { Sample St. } \\
\text { Smith, Wm. } \\
M 15000\end{array}$} & & $\begin{array}{l}\mathrm{C}_{10000 R} \\
\mathrm{~S}_{5000 a d d}\end{array}$ & $\begin{array}{l}\mathrm{C}_{22500 \mathrm{E}} \\
\mathrm{s}\end{array}$ & $\mathrm{C}_{\text {None }}$ & $\begin{array}{l}\mathrm{C}_{\text {None }} \\
\mathrm{s}\end{array}$ & $\begin{array}{l}\mathrm{C}_{N o t} A t \\
\mathrm{~s}\end{array}$ \\
\hline * & * & * & * & * & * & * & $*$ \\
\hline \multicolumn{2}{|c|}{$\begin{array}{l}1220 \text { Sample St. } \\
\text { Roe, Richard }\end{array}$} & & $\begin{array}{l}\mathrm{C}_{\text {None }} \\
\mathrm{S}^{\text {None }}\end{array}$ & $\mathrm{C}_{\text {None }}$ & $\mathrm{C}_{3000}$ & $\begin{array}{l}\mathrm{C} 3000 \\
\mathrm{~S} 4500\end{array}$ & $\mathrm{C}_{\mathrm{No}}$ \\
\hline
\end{tabular}

Without going to any of the underlying records, it seems from the above that according to information received by the Board (probably from the recorder of deeds and prothonotary, or from the tax officials of another county) Jones owned a mortgage valued at $\$ 1000$ and a judgment note valued at $\$ 500$. He made no return in 1950 , but did return $\$ 1500$ in 1951 for both county and school tax purposes. When he filed no return in 1952, the Board imposed an estimate of $\$ 1500$ plus $50 \%$ (\$750) plus $12 \%$ of the total $(\$ 270)$, or a total of $\$ 2520$. In 1953 and 1954 Jones again voluntarily returned $\$ 1500$ for tax. The Board also apparently received information that Smith owned a $\$ 15,000$ mortgage. In 1950 he returned $\$ 10,000$, whereupon the Board issued an "add" for the remaining $\$ 5000$. In 1951, when he made no return, he was estimated at $\$ 22,500$, but after appeal to the Board he was granted a $\$ 7500$ allowance. In 1952 and 1953 his return reported no taxable property, and apparently by 1954 he had moved (or at any rate he could not be contacted at that address). Roe made returns reporting no taxable property for 1950 and 1951, but in 1952 he returned $\$ 3000$ as taxable for both county and school purposes. In 1953 his return showed $\$ 3000$ taxable for county purposes and $\$ 4500$ taxable for school purposes. In 1954 he again reported that he had no taxable property. 
filed returns in the past few years or about whom information has been obtained which would lead the Board to believe that he is taxable. If no return is filed for several years and there is no information available as to the taxable property of a resident, his name is omitted from successive Blotters. Since there is no cross-index or alphabetical system to the Blotter, information about a particular taxable resident is available only if the Board knows his addresses.

The heart of the assessment procedure is the information available to the Board from other sources concerning residents' taxable property. Ever since the Act of 1885 it has been the duty of the recorder of deeds to turn over to the Board a report of all mortgages, satisfactions of mortgages, ${ }^{109}$ articles of agreement relating to land and assignments of mortgages recorded with that office; and it has been the duty of the prothonotary to forward to the Board a record of all single bills, bonds, judgments or other instruments securing a debt filed with his office. ${ }^{110}$ These reports are the major bases for checking on living resident taxpayers.

No information is available for the many categories of taxable intangibles which need not be recorded, such as loans, bills, promissory notes, bonds, stocks, certificates of indebtedness, articles of agreement not pertaining to land, and accounts bearing interest. Accordingly, it is suspected that much taxable property annually escapes taxation. ${ }^{111}$ Nor is provision made for the filing of information about trusts, although most of the large trust companies retained as trustees usually do file returns to avoid surcharge or loss of state approval. Provisions concerning estate property will be discussed later. ${ }^{112}$

Collection.-The tax as computed by the Board of Revision is entered on the Duplicate which is sent to the Department of Collections. The Board also notifies the Department if any additional assessment or allowance is made subsequently. From the Duplicate the Department prepares a bill which is sent to the taxable and, as accounts are paid, a notation is made on the Duplicate next to the amount due. The taxable is entitled to a discount for early payment or is subject to a penalty for late payment; ${ }^{113}$

109. Only recently have records of satisfactions of mortgages been included regularly in the reports sent to the Board.

110. Act of June $30,1885, \mathrm{~Pa}$. Laws 1885, No. 162, at 193 . Sections 10-15 of the Act made it the duty of the assessing body of each county to keep records of mortgages and other obligations owned by nonresidents of the county and to submit such records to the county in which the owner is resident. Gilmore, op. cit. supra note 6 , reported that of the sixteen counties he studied, only five (including Philadelphia) complied with this provision. Philadelphia still complies, and, according to the Board, now receives reports from most of the other counties.

Pa. Stat. AnN. tit. 72, $\$ 4866$ (1950) provides for the payment of ten cents to the recorder of deeds and prothonotary for every lien, mortgage, assignment or satisfaction thereof reported to the Board, but not to exceed $\$ 600$ per year.

111. See note 12 supra.

112. See text at and following note 120 infra.

113. The tax is due at the same time, and subject to the same discount, penalty, and interest provisions which are established by the counties for their real property taxes. PA. STAT. ANN. tit. 72, \$4843.1(c) (1950). A similar provision appears in the School Tax Act, PA. Stat. ANn. tit. 24, §581.35 (1950). The emergency 
however, since the time of mailing and receipt of bills depends as much on the speed of the two departments in processing the returns as on the promptness of the taxable in filing his return and making payment, the due dates for payments differ each year, and discounts seem to be the exception rather than the rule. ${ }^{114}$

The Act provides that the Department of Collections can file with the prothonotary a true copy of the amount due, and that it then becomes a lien upon the taxable's real estate until paid. ${ }^{115}$ But as a matter of practice, at the end of the year unpaid accounts are circled, the Duplicate is sent to the delinquent tax division for preparation of a delinquent tax book, and the duplicate is then filed for future reference. A master file card is prepared for these delinquent accounts and the taxable is billed and dunned for the balance of the year. Only then does the Department follow the statutory procedure by entering the unpaid amount on the Personal Property Tax Lien Docket as a lien on the taxable's real estate; and the entry is made on the master file card mentioned above, which is filed by address in the delinquent tax division's files. In recent years a second master card has been prepared at this point and filed alphabetically. ${ }^{116}$ If the tax is not collected within five years, the lien is revived by filing a writ of scire facias. ${ }^{117}$ If the account has been paid prior to becoming a lien, a notation

state tax simply set February 15 as the due date for tax payments. PA. Stat. ANN. tit. 72, $\$ 3250-4(1949)$. For an example of a Philadelphia ordinance which sets the due dates and discount and penalty provisions for the real estate taxes, see 1952 Ordinances of the CITY OF Phinadelphia 528. The severity of the penalty is proportioned to the lateness of the return.

114. While the bills for real estate taxes are issued in time to allow the discount of one per cent if paid before April 30, normally personal property tax bills cannot be issued before May or June. In practice taxpayers receive a one per cent deduction for payment within one month after mailing of the bill, no discount or penalty for the following two months and a one per cent penalty per month thereafter.

The tax also bears interest at the rate of six per cent per annum until paid. PA. Stat. ANN. tit. 72, $\$ 4881$ (a) (1950). For the School Tax provision, see PA. Stat. Ann. tit. 24, \$581.44(a) (1950).

115. The Act also provides ". . All such liens shall have priority to, and be fully paid and satisfied out of, the proceeds of any judicial sale of said real estate before any other obligation, judgment, claim, lien or estate with which the said real estate may become charged, or for which it may become liable, save and except only the costs of the sale and of the writ upon which it is made and the real estate taxes imposed or assessed upon said property. . "PA. STAT. ANN. tit. 72, \$4881(b) (1950). See also PA. Stat. ANN. tit. 24, $\$ 581.44$ (b) (1950) (School Tax provision).

116. The purpose of this second master card is to provide a cross-reference to taxpayers, and the card is filed in an alphabetical index so that the Department of Collections can tell at a glance the amount of delinquent taxes owed by any taxpayer. Although this system facilitates collection, particularly in the audit of estates, it is of recent origin, and countless thousands of dollars of delinquent taxes under older accounts are carried on the Department's books with absolutely no way of determining the present address of a living taxpayer or the status of a deceased taxpayer's estate. The Department is slowly and partially alleviating this situation by attempting to revive old liens and filing liens against the old accounts; in the process, it has been preparing a second card and filing it alphabetically, with the ultimate goal of thereby cross-referencing all old accounts.

117. PA. STAT. ANN. tit. 72, $\$ 4881(\mathrm{~b})(1950)$. Since the Act of August 19 , $1953, \mathrm{~Pa}$. Laws 1953 , No. 317 , at 1157 , a new subsection (d) has been added to this section, providing for an alternative method of reviving liens by the filing of a "suggestion of nonpayment and averment of default." PA. STAT. ANN. tit. 72, $\S 4881$ (d) (Supp. 1953). 
is made on the delinquent book and the collection card is marked paid, and filed. If the account is not paid until after a lien or a "sci fa" has been filed, the proper notation is made on the master cards and in the delinquent book after the lien is marked satisfied on the prothonotary's docket. Delinquent taxes are subject to a seven per cent penalty as soon as they are registered as delinquent, and are subject to an interest charge of six per cent for each year (computed at one-half of one per cent each month) they remain unpaid; ${ }^{118}$ therefore, before a taxpayer can pay his delinquent tax he must request and receive a new bill from the Department of Collections, unless he happens to pay the tax in the month in which a bill had been sent to him. If any additional assessments have been made for years prior to the current taxable year, a special sheet is prepared in the delinquent book and the same procedure is followed for that account, which is considered delinquent immediately. Any allowances are also noted and are subtracted from the amount owed. The books containing all the delinquencies are preserved, one each for the periods 1917-1937, 1938-1947, and 1948 to the present. ${ }^{110}$

Procedure for Estates.-Some unique problems are encountered in the assessment and collection of taxes from the estates of decedents. When a resident dies, his executor or administrator is required to petition the Register of Wills for Letters Testamentary or Letters of Administration. ${ }^{120}$ When these are granted he must advertise his appointment and also a direction that all claims against the estate be forwarded either to him or to the estate's attorney. Thirty days later the personal representative is required to file an Inventory and Appraisement, which includes a list of all property owned by decedent at death and all debts owed by or to the decedent, with the approximate dates, to the best of the representative's knowledge, that the property was acquired or the debt was contracted. Within six months thereafter, the personal representative files an Account with the Orphans' Court. A date is set for the audit of the Account by the court and at that time claims against the estate may be heard by the auditing judge. At the close of the audit the personal representative's attorney presents to the auditing judge awards for distribution which, once allowed, lead to the discharge of the personal representative and his surety, if any. The award and discharge terminate the account and relieve

118. See notes 113, 114 supra. Since ustually the tax is not filed as delinquent until a year past the January following the due date of the tax, it is immediately subject to the penalty and interest provisions, totalling thirteen per cent.

119. Although the Act turning over enforcement of the tax to the counties dates from 1913, and although the counties played a large part in the enforcement of the tax prior to that date, the records of the Board and Department date only from 1917.

There is no statute of limitations on unpaid taxes, even if they are not liened. Philadelphia v. Goldstein, 30 Pa. D. \& C. 451 (Philadelphia C.P. 1937). There is, however, a presumption of payment after twenty years.

120. Fiduciaries Act of 1949, Pa. Stat. Ann. tit. 20, $\$ 320.101$ et seq. (1950). The remainder of the textual paragraph outlines the relevant procedure prescribed by this Act. See also Memorandum dated May 14, 1953, to George S. Forde, Revenue Commissioner, from Romanus J. Buckley, Deputy Revenue Commissioner. 
the personal representative and the heirs of all responsibility for the debts of the decedent. Thus, the claim for taxes is lost if not presented prior to the award and discharge.

The Board of Revision instructs a staff member to check the Legal Intelligencer (Philadelphia) every day for the appointment of personal representatives, and to make up a card for each estate, containing the name and address of decedent, the estimate of the amount of property in the estate, and the name and address of the estate's attorney or representative. When an inventory is filed, the given address of the decedent is noted on the card. The executor of every will and administrator of every estate is required to file with the Register of Wills or clerk of the Orphans' Court an additional copy of the inventory and appraisement mentioned above, which is forwarded to the Board of Revisions. ${ }^{121}$ It is the Board's duty to make additional assessments for the preceding five years and to collect the tax by presenting a claim to the Orphans' Court for these prior five years as well as for each year of the administration of the estate. ${ }^{122}$ But even here the method followed by the Board hampers efficient assessment and collection of the tax. To learn the decedent's residences during the past five years, the Board customarily writes to or telephones the attorney, administrator or executor. If the fiduciary does not know the addresses, the Board has no way of determining whether this decedent had owned taxable property which was not returned or which was returned from an address other than the one at which he was living at death. If all the taxable property is not included in the inventory, it would be merely fortuitous if the Board discovered that fact from its information in time to file a claim. Using the addresses available, the Board searches the Blotter to determine the amount of taxable property, if any, returned by decedent for the five years prior to his death, and these amounts (or the word "None" if no return or a "none" return had been filed) are entered on the card. Then an assessor of the Board's personal property division makes a schedule of the taxable property disclosed on the inventory as owned by the decedent in each of the five years prior to death, as well as in the current year. If the property listed on the inventory corresponds to the amount returned in each year, this is noted on the card. If, however, the inventory discloses unreturned property, the Board makes an additional assessment for the preceding five years and computes the tax on the added amount. Notice of the additional assessment is sent to the fiduciary who then has an opportunity to appeal, and the "add" is noted on the card.

All of these cards are sent directly to the delinquent tax division of the Department of Collections, where the records are checked to see if the decedent owed any delinquent taxes. But difficulties of administration arise here also. The Board of Revision has received information about decedent's residences for only the past five years; but, since the delinquent taxes are

121. PA. Stat. AnN. tit. 72, $\$ 4844.2$ (1950). See also the similar provisions in the School Tax Act, PA. STAT. ANN. tit. $24, \$ 581.40$ (1950).

122. Ibid. 
filed solely by address, in order to trace the account back to 1917 the delinquent tax collector must again communicate with the attorney to attempt to determine other prior addresses from which decedent may have filed returns. Then all these addresses must be searched in the three sets of delinquent books, as well as in the Duplicate for the present year which is on file at the current tax department. All former amounts due are noted on the audit card received from the Board. A bill is sent to the attorney or fiduciary who often will settle the account without further action being taken. More often, however, the city solicitor must be notified of the amount due. An assistant solicitor will then make a claim against the estate at the audit of the account, which claim will be heard and disposed of by the auditing judge. When and if the amount due is paid, a notation is made on the delinquent tax book, thus settling the account.

Because of the difficulty in compiling information prior to the audit concerning the status of the decedent's account, the possibility that at any time thereafter further information concerning his liability for delinquent taxes might be discovered, and the fact that the estate is subject to continuing liability for taxation on the property it is administering, the solicitor seldom puts in a specific claim for the taxes believed to be due. More often he makes a general claim at the audit, thus giving the city time to determine the decedent's liability and to negotiate for a settlement with the estate. Attorneys for estates have expressed disapproval of this procedure, and have been reluctant to cooperate. If all the information were available on one master card, a specific claim could be determined rapidly, easily and with assurance that no great amount of tax would thereby be rendered uncollectible. This would speed the audit procedure and induce greater cooperation from personal representatives and attorneys for estates, as well as from the auditing judges.

\section{Suggested Solutions}

As can be seen from the above account, Philadelphia's enforcement of the tax on intangibles is hampered by a verbose, ambiguous statute and an outmoded system of assessment and collection. These problems are heightened by a lack of sufficient non-political personnel in the departments which attempt to enforce the tax. However, it is believed that a fair solution can be achieved for most of these difficulties. ${ }^{123}$

\section{Mechanics of Assessment and Collection}

Coordination of Enforcement Agencies.-At the commencement of this study, Philadelphia had just entered its second year of Democratic adminis-

123. The scope of this Note does not encompass the fiscal advisability of a personal property tax, nor the advisability in general of adding to or exempting classes of persons and property presently subject to the tax. The following suggestions are concerned primarily with improving the mechanical aspects of assessment and collection, and with providing means for increased information at source in order to limit the possibilities of evasion. However, where no means for alleviating the inequities have been considered possible, amendments to or repeal of the particular subject of the tax have been suggested. 
tration after an uninterrupted Republican reign of 67 years. The Board of Revision of Taxes was one of the last few Republican strongholds, while the Department of Collections was under the jurisdiction of the Director of Finance and of the Revenue Commissioner, both Democrats. Thus, there was little cooperation, and at times much friction, between the assessing and collecting departments. ${ }^{124}$ This was particularly apparent in the field of audits, where a smoothly functioning tax agency would produce much revenue. Both departments were understaffed and many of the personnel, particularly in the Board of Revision, continued their political activities. Shortly after this study began, a change in some of the Board's key personnel and constant investigation of the Board's activities resulted in greater cooperation between the collection agencies and in the introduction of some new assessment procedures. Although the amount of taxes assessed and collected did increase, duplication of effort still exists in the entire procedure.

A remedy might be instituted in the near future, since the Supreme Court of Pennsylvania has decided that the exemption of the Board of Revision from the city-county consolidation law was unconstitutional. ${ }^{125}$ As a result, the City Council passed a bill abolishing the Board and transferring its functions to a Chief Assessor in the Finance Department; but this measure is being litigated and thus delays further the coordination of the two departments. ${ }^{126}$

Due Date of Returns.-As indicated above, ${ }^{127}$ the return is due by February 15 and the date for hearing appeals is February 25. Thus, the estimate and notice of the appeal date must be sent to the taxpayer within ten days. This has necessitated much night work annually during this period and resulted in mistakes and omissions due to haste. These dates should be altered to permit a greater period of time to elapse between the due date and the appeal date. Returns could be due by February 1 and the appeal date set no earlier than February 28.

Enforcement Procedure.-The outmoded mechanical procedure of assessment must be altered. The system of books kept by ward and district actually hampers enforcement because, unless the taxpayers cooperate, it is impossible to keep track of the many who frequently change their

124. The City Council of Philadelphia was engaged in an investigation of the Board of Revision, with primary emphasis on the Real Estate Department, at the time this study commenced. For an account of the Council's report, see Philadelphia Evening Bulletin, Aug. 13, 1954, p. 3, col. 1.

125. Clark v. Meade, 377 Pa. 150, 104 A.2d 465 (1954).

126. For a commentary on some of the problems posed by the consolidation study, see the following series of columns by the late Clarence $G$. Shenton, noted civic authority and member of the editorial staff of the Philadelphia Evening Bulletin, as well as Secretary of the Thomas Skelton Harrison Foundation: The Philadelphia Evening Bulletin, Jan. 25, 1954, p. 13, col. 1; April 8, 1954, p. 17, col. 3 ; May 12, 1954, p. 31, col. 3. See also note 95 supra.

127. See text at notes 99,102 and notes 99,102 supra. 
addresses. ${ }^{128}$ It is suggested: first, that the laws requiring the books to be kept by street address be repealed and a machine system of accounting or some master card system be adopted; ${ }^{129}$ second, that an alphabetical reference system be adopted immediately. Although it would be an overwhelming task to put all the records from 1917 to date into alphabetical crossreference, all future accounts would be so referenced, and as many as possible of the old accounts could be brought into the system gradually to replace the old records. ${ }^{130}$

The Blotter, Duplicate, Triplicate, and Assessor's Books are unwieldy and inefficient. Except for the computation of the tax, the Assessor's Book contains less information than the Blotter; nor does it serve as an internal check on the accuracy of the Blotter, since it is prepared and kept in the same office. If the assessment and collection departments were combined under one official and located in one place with the delinquent tax division, a set of master records could be provided to replace the existing ones and establish a system ${ }^{181}$ which would provide both greater efficiency and internal checks.

Late Appeals.-Since the Board is required to hear appeals at any time subsequent to the time prescribed for appeals and prior to the payment of the $\operatorname{tax}^{132}$ the collector sometimes finds that taxes listed as delinquent are wiped out by late appeals. This not only increases the problems of enforcement but also encourages procrastination on the part of taxable residents. A taxpayer does not appear to need an unlimited time for appeals, in the absence of some inequitable action on the part of the Board; and in the latter case the courts have granted relief. ${ }^{133}$ It is suggested that the provision for appeals be amended to reenact the thirty-day limit which existed prior to 1951 .

Failure to File; False Returns. - The Act provides that no failure to assess or return shall discharge the owner of taxable property of his liability for the tax. ${ }^{134}$ Wilful failure to file a return, ${ }^{135}$ wilful submission of

128. See text following note 105 supra.

129. A similar suggestion was recently made by City Controller Foster A. Dunlap in his audit report for 1953, which cited clerical errors in the Board's records. See, e.g., Philadelphia Evening Bulletin, Aug. 18, 1954, p. 4, col. 1.

130. As explained above, see note 116 supra, the Department of Collections has already begun to do this, but, because of lack of manpower, it is highly unlikely that the Department will be able to bring its old records into this system without adding to its staff personnel.

131. One suggested system is outlined in the Appendix.

132. See note 102 supra and memorandum from the Deputy Revenue Commissioner to the Revenue Commissioner, note 102 supra.

133. See, e.g., Philadelphia v. Kolb, 30 Pa. D. \& C. 229 (Philadelphia C.P. 1937) where the court refused to give summary judgment to the city since there was no proof that the taxpayer received notice of the assessment, and therefore he may not have had an opportunity to contest the assessment.

134. PA. Stat. Ann. tit. 72, $\$ 4821$ (Supp. 1953).

135. Pa. Stat. Ann. tit. 72, $\$ 4843.1$ (d) (1950). The School Tax Act provision can be found in PA. STAT. ANN. tit. 24, \$581.45(c) (1950). No such provision appeared in the emergency state tax. 
a false return ${ }^{136}$ and an assessor's acceptance of an uncertified return ${ }^{137}$ are each declared a misdemeanor. However, there have been no instances in recent years of prosecution for these offenses. It is suggested that a provision be written into the Act requiring that all returns be sworn to before a notary or before an assessor who has the power to administer an oath. ${ }^{138}$ In addition, these provisions should be enforced strictly, but it would seem highly unfair to do so without some notice after such a long period of quiescence, especially in light of the widespread lack of knowledge of the existence and provisions of the tax law. Publicity concerning the Act should, therefore, accompany the notice of an intention to enforce the act strictly.

The Board may make an assessment against a delinquent taxpayer at any time within five years, regardless of whether or not the taxable paid a tax on the basis of his previous inadequate returns, and in spite of any previous assessments. ${ }^{139}$ In the case of a false return filed by the taxable, the twelve per cent penalty may not be cancelled.140 However, the Board does grant relief if a conference with the taxpayer shows that he is not being merely obstreperous and is willing to settle his liability on a basis satisfactory to the Board. Since many residents take advantage of the Board's leniency in this respect, the provision forbidding relief from the penalty should be observed. The five-year limit, moreover, is probably the most practicable and equitable one in the ordinary case; but if it can be proved that a taxpayer attempted to defraud the city of the tax, he should be prohibited from invoking the statute of limitations. This would be similar to provisions in the Federal Internal Revenue Code and many criminal statutes. ${ }^{141}$ The five-year limitation on the assessment of decedents' estates ${ }^{142}$ also should be tolled if fraud by a decedent can be proved. Because of the difficulty of proving fraud, this provision probably would not

136. PA. Stat. AnN. tit. 72, §4842 (1950). For the School Tax Act provision, see Pa. Stat. ANN. tit. 24, $\$ 581.45$ (b) (1950). The emergency state act declared it to be perjury to make a wilfully false return. PA. STAT. ANN. tit. 72, §3250-8(a) (1949).

137. PA. Stat. AnN. tit. 72, $\$ 4843$ (1950). There is no similar provision in the School Tax Act.

138. Objection to this suggestion has been made on the ground that it amounts to unnecessary harassment of the taxpayer. It is believed, however, that such a requirement is an effective psychological device in inducing the taxpayers to assume their burden. For example, an employee of the Department of Collections has observed that collections of delinquent taxes increased when the prothonotary began printing.an impressive red seal on the writ of scire facias sent to the taxpayer.

139. Pa. Stat. Ann. tit. 72, $\$ 4844$ (1950). The School Tax Act provision appears in PA. Stat. ANN. tit. 24, \$581.37 (1950). See note 101 supra. The penalty imposed by the county act was formerly fifty per cent, but it was changed to the present twelve per cent by the Act of July 3,1947, Pa. Laws 1947, No. 513, at 1249.

140. PA. Stat. ANN. tit. $72, \S 4844$ (1950). The School Tax Act provision appears in PA. Stat. ANn. tit. $24, \S 581.37(1950)$.

141. 26 U.S.C. $\$ 6501$ (c) (1) (2) (1954). See also, Note, 102 U. of PA. L. Rev. 630, 639-41 (1954) (concealed crimes).

142. Pa. Stat. Ans. tit. 72, $\$ 4844.2$ (1950). The School Tax Act provision appears in PA. Stat. ANN. tit. $24, \S 581.40$ (1950). 
be invoked very often, but it would have an in terrorem effect and would prove valuable in preventing the most flagrant violations which escape at present with light punishment at most.

Audit Procedure.-Although the Board is directed to assess and collect taxes owed by the decedent for the five years prior to death, the Board does not do so if the taxable assets in the estate total less than a certain minimum, usually about $\$ 5000$. This practice rests on the assumption that the forty dollar tax on such an amount does not justify the work involved. But this theory overlooks several factors which may lead to the loss of more tax than would seem apparent. First, the decedent may owe great amounts of delinquent taxes for former years for which he had been assessed and billed, but which he had never paid; unless a card for the estate is prepared and forwarded to the Department of Collections' delinquent tax division, ordinarily the delinquency will not be discovered. However, the division reaches many omitted estates by customarily making its own check of the Legal Intelligencer to discover when personal representatives for an estate have been appointed. This procedure involves much duplication and it should be coordinated. A master card system would do much to alleviate the situation by making all the information as to assessment and collection available at one place for a simplified checking of each estate. No sizable amount of tax would then escape collection and the amount of work presently involved in the audit procedure would be reduced considerably. A second reason for not ignoring any estates is that assets which are taxable to the estate may be acquired during the administration. Even though copies of these further inventories are filed with the Board, there is little follow-up on the estates and consequently much of this source of revenue remains untaxed. Again, a master card system would alleviate much of the difficulty. Lastly, the distribution of the estate should be traced so that the taxable assets will be taxed in the hands of the beneficiaries, creditors or purchasers from the estate; this would form a new area of information at the source for the Board's records and would cut down the possibility of evasion by the recipients of the property.

Difficulties Due to Addresses. - The tax is levied only on residents and thus a person working in Philadelphia need not pay the tax if he lives in another state. ${ }^{143}$ Many people can evade the tax by assuming as their residences their summer homes in other states, such as New Jersey, which do not impose such a tax, or by putting their property under the management of an agent with an out-of-state address. The introduction of an alphabetical reference system would minimize this means of evasion by enabling the Board to discover that an apparently taxable resident files no return from his Philadelphia address, but does file a return with a nonresident affidavit, or has his agent do so from an out-of-state address.

In a similar manner the Board's information at source is deficient. For example, when seeking to record a mortgage, the mortgagee is supposed

143. See text at note 87 and note 87 supra. 
to insert his proper address on the back of the mortgage; ${ }^{144}$ but the recorder of deeds is lax in enforcing this requirement. Thus, he might consult the telephone book to find the address and, if there are several names similar to the mortgagee's, any one might be chosen. Since the Board lacks an alphabetical file, it has no way of checking on this type of mistake, which is not uncommon. A further difficulty is presented by the fact that often several creditors will lend money on the security of a single mortgage. The Recorder of Deeds should include this fact with the information which he is required to send to the Board. However, this is sparsely enforced also, thus causing a failure to assess some of these taxable creditors.

The possible solutions to these problems are: first, require the nonresident affidavit to be taken under oath before a notary or before a personal property assessor, ${ }^{145}$ with enforced penalties for false oaths, and require an alphabetical reference file by which the Board would be able to check addresses; second, when an agent or trustee files a return, require him to include the owner's, as well as his, address, thus enabling the Board to spot-check for any attempted evasion; third, require the mortgagee's address to be included in the body of the mortgage, which is under oath and notarized, and require the Recorder of Deeds to refuse to record it unless properly filled in under oath; finally, declare the filing of false addresses a misdemeanor. Rigid enforcement is needed for these provisions as well as for the one which requires the Recorder of Deeds to include in his report to the Board the names and addresses of all the mortgagees of each mortgage.

Execution.-Although the Board can procure a lien on a taxable's real estate for unpaid taxes, ${ }^{146}$ the Act does not provide for independent execution on that lien by the Board or Solicitor. The amount due may be collected by a suit in assumpsit, by a claim at the audit of the estate, or by a

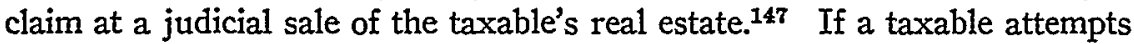
to sell any of his real estate, the lien will prevent the sale because of the inability to obtain title insurance. But for anyone who does not wish to sell his real estate and who incurs few other debts which might become judgments against him and result in judicial sales at which the tax lien could be satisfied, the lien is an ineffectual sanction, and often a delinquent is able to postpone payment of the tax indefinitely.

A relatively simple solution to this problem would be a provision for easy execution. The resulting danger that a judicial sale, with its con-

144. PA. StAT. ANN. tit. 72, $\$ 4861$ (1950). No provision is contained in the School Tax Act, probably because the school tax officials are the same as those for the county tax.

145. Even those who object to the requirement of a sworn return by residents, see note 138 supra, admit that such a requirement in the case of a nonresident return is not an unfair proposition, since the nonresident is claiming complete exemption from the tax.

146. PA. Stat. AnN. tit. 72, §4881(b) (1950). PA. Stat. AnN. tit. 24, $\$ 581.44$ (b) (1950) (School Tax Act). See text at note 115 and note 115 supra.

147. Ibid. 
comitant costs and fees, might be invoked to recover small amounts of taxes could be alleviated by prohibiting the execution until a minimum amount is due (for example, $\$ 300$ ) or until the taxable is a number of years in arrears (for example, five). This would protect the taxpayer and yet assure the Board that it can collect taxes when the amount becomes great enough or when the evasion has been so extended as to be flagrant.

Furthermore, no execution is permitted against personal property under existing law, nor does the tax become a lien on it. By making the tax a lien on personalty and permitting attachment or garnishment, or participation in attachment or garnishment instituted by other creditors, an inexpensive means of enforcement would be introduced. To protect the taxpayer, certain necessities, such as clothing and essential household furniture, should be exempted, and a minimum amount should be due before the provision could be invoked. But the threat of attachment of an automobile or television set probably would induce more prompt payment of taxes.

Tax Date.-A problem which has led to little litigation in the past, but which is a potential source of evasion, is the use of a single tax date for determining the amount of taxable property. Only those intangibles owned or possessed on January 1 of each year are taxable for that year. ${ }^{148}$ A taxable resident could "sell" or "assign" his intangibles some time in late December to a "straw man" in another state which does not levy an intangibles tax, and then "buy" it back in early January. ${ }^{149}$ Even if the neighboring state levies an income tax for the year, as does New York, ${ }^{150}$ the tax would be negligible on the small amount of income which might accrue during that period. A court would probably look to the substance and not to the form of the transaction to recognize this as a means of evasion and hold the true owner taxable; but under the present system of information at source these transactions are difficult to discover, since there is no one place where a record of the taxable's transactions is compiled and made subject to scrutiny. A master system of records would serve this purpose and abnormal activity just before the tax date could be detected easily and investigated.

A related method of evasion is also very difficult to discover under the present recording system. A person accepting a mortgage or entering judgment by confession near the end of the year may postpone the recording until after January 1. Thus, it will not appear on the Board's books until January, although the Recorder of Deeds and prothonotary do

148. See text at note 97 and note 97 supra. The date varies throughout the counties in the state, but most are either December 31 or January 1. See GILMone, op. cit. supra note 6, at Appendix V.

149. The Chief Clerk of the Board of Revision has recently started a search of the mortgage books to uncover instances of such transactions or of the related practice of late recording of mortgages granted just prior to the tax date. Several taxpayers were called in for conferences when it was suspected that some scheme of this type was being utilized.

150. N.Y. TAX LAw $\$ 350$ et seq. As the revenue from this source was declining, New York eliminated its personal property tax in 1933. Id. introduction, at 14-15. 
disclose the actual date of the mortgage or judgment as well as the date of recording. The Board has instituted recently a system of checking the index of all mortgages recorded in the first few weeks of January and of going directly to the mortgage to determine the actual date of its grant. Since the Act taxes all mortgages, those granted during December but not recorded until January would still fall within the Act. If any are discovered, the Board now makes an assessment. While it is true that the danger of this form of evasion is lessened by other considerations, such as the fear that intervening liens or other mortgages will obtain priority if there is a delay in recording, many delayed recordings have been discovered, and it is possible that many more have not been detected.

These problems can be solved by eliminating the use of a single tax day and by levying the tax on all property owned or possessed within the state at any time during the year. The value of the property would be taxed in proportion to the length of time held in the state. It is hardly equitable that a judgment creditor whose judgment is recorded in late January and marked satisfied in December pays no tax, while one whose judgment is recorded in December and satisfied in January pays a tax on its full value. Under the solution proposed, the first creditor would pay a tax on eleven-twelfths of the judgment's value, while the second would pay the tax on one-twelfth of its value. This would establish an equitable distribution of the burden of the tax by measuring more accurately the extent of the protection offered to the holder of intangibles, a protection which really lies at the basis of a property tax.

\section{Classes of Property and Persons Taxable}

A large portion of many classes of taxable intangibles escape tax because of the impossibility under the present laws of obtaining information as to the possession of this property. Any of the categories which need not be recorded are potential sources of evasion. The following suggestions are offered to alleviate this problem in certain fields and to suggest amendments in others.

Securities.-Foreign companies which do not do business in Pennsylvania are not required to pay corporate taxes in this state, and thus their stocks and bonds are taxable and should account for a large percentage of the total revenue of the tax. ${ }^{151}$ There are two important sources of in-

151. Since the Board does not keep a record of the valuation returned for each category of property, it is impossible to determine the amount of tax attributable to the various categories. But the writer took a random sample of some of the 1953 returns filed in two representative districts to see if any tentative conclusions could be drawn. Only a few of the many thousands of returns filed were inspected and they amounted only to a small portion of those filed in the two districts chosen; but it is believed that the figures obtained are roughly representative.

One of the chosen districts is in the center of Philadelphia, and includes both offices and residential apartments, where in all probability many attorneys and agents file returns from their offices and many professional people with income from stocks and bonds live. Of 159 returns, 120 contained stock totalling $\$ 2,536,295$; 39 reported no taxable stock. Eighteen reported mortgages valued at $\$ 1,229,014$, of which one 
formation as to the possessors of stocks and bonds. When a taxable dies, the securities will be included in the inventory filed by his estate, with the approximate dates of ownership. But a taxable can avoid his obligation for several years and, if the evasion is detected, the Board can assess against the estate only for the five years immediately preceding death. A second source of information is the reports of trust companies and large reliable companies which act as trustees of stocks and bonds for taxable beneficiaries. Most of the trustees will pay the tax without further inducement, but there is no means of checking on those which do not pay. Even if they were required to file a copy of the trust deed, it would not afford information as to the type of property held at any given time and managed by the trustee. A third but extra-legal source of information is the lists of stockholders, which are purchased by the Board from brokers and other sources. But two limitations, besides the questionable legality of such disclosures, attend the use of these lists; first, they are only a partial source of information, since only a few brokers will sell them, and since they do not contain information about purchases made outside the state or on the open market not through brokers; second, even if all Philadelphia, or all Pennsylvania, brokers were required by law to provide this information to the Board, prospective investors who want to evade the tax would patronize out-of-state brokers. A more practicable solution would be to obtain the cooperation of the Internal Revenue Bureau. All companies are required to file an information list with their income tax returns, indicating the dividends they have paid during the year and the persons to whom such dividends are paid. ${ }^{152}$ The Internal Revenue Code provides specifically that this information may be made available to local taxing authorities on the request of the governor of the state. ${ }^{153}$ Since the information is now

alone was worth $\$ 931,712$, while 141 reported no taxable mortgages. Four reported the possession of judgments valued at $\$ 24,961 ; 23$ reported bonds worth $\$ 100,034$ taxable for county purposes and 21 reported bonds valued at $\$ 187,930$ taxable for school purposes. Only 4 returns reported any of the other forms of taxable property.

Two hundred forty-seven returns were studied from one of the industrial districts located in northeast Philadelphia, where one would suspect that most of the property reported would be mortgages owned by the many real estate brokers and wealthier landowners in the area, but where little stock or bond ownership would exist. Fifty-seven of these returns reported ownership of stocks worth $\$ 417,600$; of this one return alone reported stock valued at $\$ 130,023 ; 190$ reported no taxable stock owned during the year. But 133 listed mortgages worth $\$ 797,622$, and less than half, 114, reported no mortgages. Eleven returned judgments valued at $\$ 10,963$; 6 reported owning $\$ 11,651$ worth of promissory notes; only 2 owned bonds taxable for city purposes at $\$ 381 ; 2$ others returned bonds taxable for school purposes at $\$ 1700$. Only 3 others reported other classes of property.

Keeping in mind the limitations of the small sample, the inferences that can be drawn from this survey are: (1) although there are no accurate checks on the holders of stocks and bonds, many people do list this property and actually it is one of the most productive categories of taxable property; (2) mortgages are clearly the second most productive class; and (3) in spite of the information concerning judgments, very little revenue can be attributed to that class of property.

152. INT. Rev. CODE of 1954, $\$ 6042$.

153. INT. REv. CODE of 1954, $\$ 6103$ (b) (2). See Doherty v. Board of Chosen Freeholders of Hudson County, 131 N.J. Law 556, 37 A.2d 92 (1944). 
recorded on IBM cards, a "run" of all the Philadelphia residents receiving dividends would not be difficult. While this would include only those receiving dividends, it would still be a partial check and would provide a source of useful information for succeeding years. Also, the list would name those who should be taxed, i.e., the holders of productive stock. Investment business would not be driven out of the state since stocks purchased elsewhere would appear in the records anyway.

A further incentive to evasion arises from the fact that the tax is levied on all taxable securities, regardless of their productivity. Although the value of securities depends to some extent on their productivity, the values used by the Board ${ }^{154}$ to determine taxability are not an accurate barometer. It seems inequitable to require the holders to pay a tax of nearly one per cent of the listed value of stocks or bonds which may produce little or no income during the year, particularly on those stocks held solely for speculative purposes. Of course it has been held that a taxpayer may prove that his security is worthless as of the tax date, regardless of the value placed on the security by any of the quotation services; ${ }^{155}$ and, of course, stock is not worthless merely because it does not yield dividends, since it is usually of some value as a speculation or as a share in the net assets if the corporation should terminate business. But some states have instituted a more equitable means of taxation which might well be adopted by Pennsylvania. This method either exempts nonproductive securities or taxes them at a lower rate than productive securities. ${ }^{156}$ The definition of a productive security could take into consideration the percentage as well as the frequency of dividends declared. ${ }^{157}$

154. Referring to several services, the Board uses the values assigned to the securities according to their trading prices on organized markets as of that date. For the value of stocks, the reference is to Prentice Hall, National Daily Services, National Quotation Bureau, and Fitch's Service; for the valuation of bonds, reference is made to Moody's and Standard \& Poors' Manuals, as well as to National Quotation Bureau and Fitch's.

155. In re Davis, $349 \mathrm{~Pa} .651,37$ A.2d 498 (1944) (Allegheny County personal property tax assessment cases).

156. For example, Ohio taxes productive investments at the rate of five per cent of their income yield, but levies only a two mill tax on unproductive investments, deposits, and shares in and capital employed by financial institutions; a five mill tax on shares in and capital employed by dealers in intangibles; and a three mill tax on money, credits and other taxable intangibles. OHIO GEN. CODE ANN. \$\$ 5638, 5638-1 (Paige 1950). Florida classifies intangibles and levies a different rate of tax ranging from one-twentieth of a mill to three mills per dollar on the various categories. Fla. Stat. AnN. c. 199, \$199.01 et seq. (1943; Supp. 1953). Michigan imposes a tax of three and one-half per cent on the income, but not less than onetenth of one per cent of the face value of income-producing property, and one-tenth of one per cent of the value of non-income-producing property; one-twenty-fifth of one per cent of the value of moneys on hand or on deposit, and of stock in building and loan and savings and loan associations; five and one-half mills per dollar of the book value of stock of banks and trust companies. MICH. STAT. ANN. $\$ 7.556$ (1) et seq. (Cum. Supp. 1953). Missouri limits its tax to those intangibles having an income yield, the tax being at the rate of four per cent of that yield. Mo. ANN. STAT. \$146.010 et seq. (Vernon 1952). For provisions in other states see TAX Systems (C.C.H. 13th ed.; Cum. Supp. 1954), under category 20 (property taxes, particularly 20.1, intangibles taxes).

157. See, e.g., Ohio's provisions, note 156 supra. 
Mortgages.-In addition to the administrative solutions suggested above, ${ }^{158}$ better enforcement of the tax on mortgages would be achieved by a law prohibiting the recorder of deeds from having the mortgage marked satisfied until he receives proof of payment of the personal property tax. ${ }^{150}$ However, this solution may have some unfavorable repercussions. A1though the mortgagee has the sole liability for the tax, ${ }^{160}$ the mortgagor is the one most interested in having the mortgage marked satisfied. Thus, the proposed sanction against the mortgagee's non-payment would fall most heavily on the mortgagor. He would then be forced either to forego recording the satisfaction or to pay the tax. This could be remedied by a further provision authorizing the mortgagor to require the mortgagee to give him periodic proof of payment of the tax. If proof is not forthcoming, the mortgagor would be allowed to deduct the tax from the last payment of interest and principal and to turn it over to the Board in return for a receipt entitling him to have his satisfaction recorded. Of course, any stringent enforcement may have the effect of driving up the interest rate on mortgages so that in the long run the mortgagor will be the one bearing the burden of the tax. But this is true of any similar property tax and is a question of tax policy for legislative consideration.

Judgment Notes.-A common form of instrument in Pennsylvania is a confession of judgment note, ${ }^{101}$ by which the debtor confesses the debt and authorizes any attorney to enter judgment against him on the note merely by presenting it to the prothonotary. These notes are used in a substantial number of financing situations. Many holders of such notes follow the practice of entering judgment immediately upon their receipt, although execution cannot be obtained until after default in payment of principal and/or interest. These judgments are recorded by the prothonotary, and the information is relayed to the Board. But holders who enter judgment only after default can postpone payment of the tax, because the information would not be available to the Board until the date of recording. While this is not a serious problem today because most of the notes are of short duration and would not ordinarily be possessed on more than one tax day, if at all, they might enter into the computation of the tax of two years if the suggested provision taxing property possessed at any time during the year were adopted. Information at source could be made available, however, in much the same manner as suggested above for mortgages. The prothonotary could be required to demand proof of payment of the

158. See text at and following note 145 supra.

159. For example, Indiana has a similar requirement in its personal property tax law. It requires the affixing of a stamp to taxable intangibles when the tax has been paid, and the sale, transfer, revival or enforcement of any unstamped taxable intangible is prohibited. IND. ANN. STAT. $\$ \$ 64-901$ et seq. (Burns 1951).

160. If the mortgagee requires the mortgagor to pay the tax, the amount is considered usury and is subject to the usury laws. PA. STAT. ANN. tit. 72, $\$ 4884$ (1950); Pa. Stat. AnN. tit. 24, §581.45(a) (1950) (School Tax Act).

161 See Note, 102 U. of PA. L. Rev. 524 (1954). 
tax to date before accepting judgment notes for recording, and the court could be ordered to refuse to allow enforcement if it could be proved that no taxes were paid. The prothonotary, moreover, should be required to send to the Board the date of the note as well as its date of recording, thus providing greater information for the Board's records.

Promissory Notes, Accounts Bearing Interest, Articles of Agreement.-Since debts evidenced by paper other than judgment notes usually are not recorded in any public place, it is almost impossible to obtain information as to their ownership. The suggestion for alleviation of this problem is again to require proof of payment of the tax before the court permits judgment to be entered. If the taxable does not make any payment until he brings suit, he will be subject not only to the penalty and interest provisions of the Act, but also to prosecution, if it can be proved that his evasion was wilful. It is also suggested that failure to pay the tax until just prior to suit on the debt should be grounds for reopening the taxpayer's returns for former years and for admitting proof of fraud or wilful evasion of taxes in those years. However, the taxpayer can always avoid payment of the tax on debts or notes upon which suit is not brought. Thus, only those holders who are forced to bring suit on their notes will be fulfilling their obligation to pay the tax. If the legislature considers this inequality to be a sufficiently 'serious problem, that portion of the tax should be repealed. ${ }^{\mathbf{1 6 2}}$

Bailment Lease Financing.-The lessee-purchaser of property under a bailment lease arrangement holds no taxable property; nor is the lessorvendor taxable as to his title interest retained. ${ }^{103}$ The potential taxable incident is the resulting debt, usually evidenced by a judgment note for the full amount of the lease and purchase price. Many installment houses use this method of financing sales; ordinarily, if the lessor-seller would be in the category of persons amenable to the intangibles tax, the note he holds would fall within the taxable category. But most installment houses follow a policy of discounting these notes immediately with a bank or finance company, which is not a taxable holder of the note. Thus, the entire transaction escapes taxation at present. But generally the installment house, in setting up its arrangement with the bank or finance company, also agrees to remain secondarily liable on that note in case of default, and reserves the right to enforce it against the debtor. ${ }^{104}$ Because of this, for some purposes the finance company and installment house are considered to have a unity of interest sufficient to make the finance company a party

162. Only a small amount of revenue is collected from this category of taxable property. While the Board does not keep records of the valuation of the various classes of property, a survey of thousands of returns indicated that promissory notes were found on only very few of them.

163. See text following note 60 supra.

164. See the description of bailment lease transactions with confession note attached in Note, 102 U. of PA. L. REv. 524, 534-35 (1954). See also cases cited note 165 infra. 
to the note. ${ }^{105}$ It is suggested that the converse may well be considered true for the purpose of intangible taxation. Even though it seemingly does not continue to hold the note, the installment house remains the true creditor and, therefore, it should be subject to tax on the note. Such a holding would open a large new source of revenue to the city; on the other hand, it might have the unfavorable effect of forcing up the installment interest rate to absorb some of the added burden. However, it should be considered as a possibility.

Equitable Interests; Trusts.-The intricacies of the taxable incidents of a trust arrangement have been discussed above.180 The existing statutory provisions result in anomalous situations which may tend to drive the management of trust estates out of Philadelphia, perhaps into near-by Camden or into New York City, neither of whose states tax intangible property. ${ }^{167}$

165. Mutual Finance Co. v. Martin, 63 So.2d 649 (Fla. 1953) (finance company held to be so involved in the transaction as to have notice of note's infirmity); Commercial Credit Corp. v. Orange County Machine Works, 34 Ca1.2d 766, 214 P.2d 819 (1950) (finance company held to be substantially a party to the transaction and consequently not a holder in due course of the note and thus subject to personal defenses). See Note, 102 U. of PA. L. REv. 782 (1954).

166. See text at and following notes 63,66 supra.

167. The best way to illustrate this is to assume a series of hypothetical situations and to determine the tax effects in each. Thus: (1) Assume a trust of $\$ 10,000$ is established by a resident settlor; Beneficiary $A$ has a life interest in the income from $\$ 3,000$ and is a resident of Philadelphia; Beneficiary $B$ has a life interest in the income from $\$ 4,000$ and is a resident of Philadelphia; Beneficiary $C$, a New York resident, has the entire interest in $\$ 3,000$ and is entitled to the remainder of the $\$ 7,000$ after the other life estates. Trustee $T$ is a resident of Philadelphia, and Trustee $T / N$ is a resident of New York; the trust is managed in Philadelphia. Since the trust is managed in Philadelphia, the entire res of $\$ 10,000$ is taxable to $T$ in and by Philadelphia.

(2) Assume the same facts as in illustration (1), except that the management of the trust is moved to New York.

The trust would not be taxable to $T$ under the act, nor to $T / N$ (who could not be taxed since not within the jurisdiction nor is the property). Under the act, only the beneficial interest of the residents would be taxed. $A$ and $B$ would have to pay tax on their beneficial interests, since they are both entitled to receive part of the income from the property. If they were entitled only to principal, not to income, they would not be reached under the terms of the act. A formula for ascertaining the taxable part of the value of the entire personal property is given in the act, and the interest of each life tenant would be determined actuarily depending on their age and life expectancy. See 2 STRADLEX \& KRERSTEIN, op. cit. supra note 6, at $385-93$, which raises some interesting questions in the valuation of part interests, such as when a beneficiary with an interest in the principal and income outlives his expected life span. At any rate, something less than $\$ 7,000$ is taxed.

(3) Assume the same facts as in illustration (1), except that the trust was established by a nonresident settlor (or from the proceeds of property acquired from a nonresident), and that $T$ is the only trustee (or that there are joint trustees and the trust is managed in Philadelphia).

$\$ 7,000$ would be taxable to $T$. $\$ 3,000$ escapes tax, since the act exempts the portion received from a nonresident for the benefit of a nonresident beneficiary ( $C$ here). This is more than is taxable under illustration (2), where only the beneficial interest in $\$ 7,000$ principal is taxed. If the trust in this illustration were managed outside of Philadelphia, then only the beneficial interests of $A$ and $B$ would be taxed, just as in illustration (2). (4) Assume a nonresident settlor and nonresident beneficiaries; the sole trustee is a Philadelphia resident (or there are joint trustees, some of whom are Philadelphia residents and the trust is managed in 
The solution to this problem will involve a change in legislative policy. It seems that the main incidents of the tax are intended to be the possession and enjoyment or ownership of the property. If a tax is desired which will measure the amount of protection given to trustees, it is suggested that an excise or privilege tax be levied on the creation of the trust or on the privilege of being a trustee, measured by the amount of property the trustee handles. There is no real justification for attempting to tax the res of the trust to the trustee, even though he is resident and manages the trust in this state; a tax on intangibles should reach only the value of the equitable interest owned by the beneficiary.

If this suggestion was adopted, better information at source would be required. Pennsylvania trustees could be required to file a return, disclosing the names, addresses, and respective interests of the beneficiaries every year. The trustee could be made secondarily liable for tax not paid by the beneficiaries, or there could be a system of withholding from the annual payments the amount of the tax, such as the corporate loans provisions presently require of all corporations with resident treasurers which pay interest on taxable loans. Of course, since the state has no jurisdiction over nonresident trustees, there could be no such withholding at the source, and the $\operatorname{tax}$ on the beneficial interests would have to be collected from the beneficiaries themselves without a reliable source of information being available as to their identity. But the amount of revenue so lost would be negligible compared to the amount which currently escapes tax.

\section{Coordination of School and County Taxes and Tax Rates}

To facilitate administration, it would be desirable to modify the school and county taxes so as to have them fall upon identical property. Even now, although there is some difference in the classes of property taxed, there is very little variation in the amount of revenue. Under the proposed amendment it would be necessary merely to multiply the amount of taxable property by eight mills and to divide the proceeds equally between the county and the school district. Also, Pittsburgh residents now pay a ten mill tax, Philadelphia residents pay eight mills, and all other Pennsylvania residents pay only the four mill county tax..$^{168}$ These variations may well lead Philadelphia and Pittsburgh residents to evade the tax or to invent devices, such as appointing agents in other counties, which would enable them to file their return from another county or even another state. Thus it would be wise to provide a uniform rate throughout the state either by enacting a tax for the benefit of all other school districts,

Philadelphia). Nothing is taxed, since the property was received from a nonresident for the benefit of nonresidents.

The net effect of these provisions as illustrated here is that it is possible to minimize (or eliminate entirely) tax liability by managing the trust elsewhere. During the time which this author spent in the Department of Collections, more than one attorney indicated his intention to counsel clients to establish trusts out of state in order to avoid this tax.

168. See note 9 supra. 
repealing the school district tax entirely, or making a provision that property subject to this tax should not be liable for any other taxation in the state.

\section{Clarification of Returns and the Statute; Publicity}

The returns sent to citizens today are needlessly long, complicated, and close to incomprehensible to the lay citizen and even to lawyers. Because of its growth by accretion and its interpretation by the courts, the statute itself is verbose, complicated, archaic and ambiguous. The writer heartily endorses the suggestion made elsewhere ${ }^{169}$ that the Act be redrafted in paragraph form in modern language, taking into consideration all the court decisions, grouping all the subjects of the tax together, and grouping all exemptions together. With such a redrafting, a new return could be prepared which would simplify the taxpayer's task. A place should be provided on the return where the taxpayer could compute the amount of tax due. Any corrections and adjustments could be made in the same manner that the Federal Government administers its income taxes and as the city does its wage tax. The instructions on the back of the return could be made comprehensible to lawyers and laymen alike.

Finally, it is suggested that a large but inexpensive publicity campaign be conducted. Probably the most effective method of publicizing the tax would be for the city to institute a few suits for enforcement and for prosecution of evaders. This method proved very effective recently in the enforcement of the city wage tax, and the resulting newspaper publicity would give notice of the city's intent to enforce the tax equitably, but strictly. Another method found recently to be a great revenue producer is to send returns to a large sample chosen from voter registration lists. ${ }^{170}$ Finally, effective use could be made of feature articles in newspapers and of legal periodicals; pamphlets and leaflets could be distributed to stockholders, real estate brokers, finance companies, banks, installment houses, and other persons involved frequently in taxable transactions; and information could be given further distribution through the prothonotary, recorder of deeds, register of wills, or clerk of the Orphans' Court.

\section{Concluston}

In spite of the difficulty of enforcement and the potential unfairness of a tax on intangible personal property, some counties in Pennsylvania, especially Philadelphia, still find it a sufficiently convenient revenue producer to justify its continued existence. But there is no justification for

169. See Pennsylvania Commitee on Continuation of the Tax Study, supra note 2 .

170. For example, in December, 1953, the Board mailed out 45,878 of these "flyers" and the valuation returned on them totalled $\$ 6,276,570.70$ for county purposes and $\$ 6,789,264.45$ for school purposes. Collection of the total tax on these amounts would produce revenue of over $\$ 50,000$. 
the discrimination which results from imposing the burden on only a segment of those who are liable to the tax. The amendments and new administrative methods proposed here not only would serve to minimize the present inequality of imposition, but also would produce substantially more revenue than in the past.

\section{APPENDIX}

\section{Suggested Card System for Collection and Assessment of the Personal Property TAX.}

If the assessment and collection departments were combined and consolidated, and a machine system of records adopted, much work could be saved and more efficient records would be available. The present four sets of bulky, unmanageable books kept by the Board and two additional sets kept by the Department of Collections would be rendered unnecessary. It is possible to construct a system in which a maximum of five cards need be prepared for each taxpayer's account, and much of the information on all of them could be supplied at one time and entered on all with only one insertion in a machine. This would eliminate the present problem of errors in transcription arising from the need to copy from one record to another.

Whenever a new account is opened for a taxpayer, five cards would be prepared simultaneously: (A) the master file card (replacing the present Blotter, Assessor's Book, Duplicate, and Delinquent Book); (B) a duplicate (replacing the present triplicate), which would be sent to the City Controller's Office for audit and for the preparation of reports; (C) the ward file card and (D) the alphabetical file card, two cards prepared for cross-reference purposes, the first filed by address and the other filed alphabetically by name; (E) the assessor's card, for the information of the assessor. The master file (A) would contain the taxpayer's name, his present address, any former addresses available, and space for new addresses as the taxpayer moves, each such new address to be dated (thus providing a check on the place his return should be filed from each year); his ward and district next to each such address; the name and address of his attorney, accountant or fiduciary; it would also contain a series of columns headed: (a) "year"; (b) "assessor's initials"; (c) "property" (containing the total amount of property which taxpayer is believed to have possessed for that year, prepared from a supporting schedule on the reverse side of the assessor's card, described below); (d) "returns, date" (containing the amount of property the taxpayer returned and the date of his return) ; (e) "Estimates, Adds, or Allowances, date" (containing the amounts of any estimates, or adds made or allowances granted and the date of such action by the Board); (f) "tax due" (column (d) plus or minus column (e) multiplied by the current rate); (g) and (h) would be called "payments, date," broken down into a column entitled "discount, interest, penalty" (containing the amount of any discount taken by the taxpayer or the interest and penalty charged to him at the time of collection) and a second column entitled "total" (containing the total amount of taxpayer's payment; this column (h) plus or minus column $(\mathrm{g})$ should equal the amount due as listed in column (f) ) ; (i) "Lien, Sci. Fa, Suggestion, Satisfaction" (a notation of the date when registered as a delinquent tax and a lien filed or when the lien is revived, and the number of such lien, "sci fa," or suggestion of nonpayment, and the date when such a lien is marked satisfied). Each card would be divided horizontally into as many rows, each representing a year and subdivided to provide space for county and school information for each year, as is practicable to place on such a card.

The duplicate (B) would be prepared at the same time as the master file card, and would contain the taxable's name, addresses, wards and taxable districts, name and address of attorney or representative; columns (a), (d), (e) and (f) on this card would be identical to those columns on the master file, but the others would be left blank.

The card to be placed in the ward file (C) would contain only the taxpayer's name, present address (by which it would be filed), former addresses, wards and districts. The rest of the card would be left blank, since its only purpose is for cross-referencing to the alphabetical or master files if necessary.

The alphabetical file card (D) would be used for compiling information concerning collection of the tax; it will contain all the information (addresses, etc.) 
contained on the top of the master card; columns (a), (d), (e), (f), (g), (h) and (i) will be the same as those on the master file. Only columns (b) and (c) will differ; (b) will be entitled "collector's initials," and will contain the initials of the member of the Department of Collections who contacts the taxpayer or his agent; (c), entitled "Type of contact, result" will contain a notation of the type of call made (personal, telephone, correspondence) with a notation of the result of the contact. This card will be used for the purposes of attempting to collect the tax due, both current and delinquent, so that it will show the status of the taxpayer's entire account with the city, just as would any corresponding account in a department store or credit organization.

Finally, the assessor's card (E) would contain the same name and addresses and other information as appears on the top of the master card; columns (a), (b) and (c) will be identical to those on the master's. The rest of the card will be left blank to provide space for the results of any contacts with taxpayer or his attorney.

On the reverse side of the assessor's card would appear a detailed schedule of the supporting information necessary for the entry of the total figure in column (c) of the master and assessor's cards. This schedule will be divided into as many columns as there are taxable types of property; it will contain two extra columns entitled "satisfied" and "years in which taxable." It will be divided into numerous horizontal rows, each representing a new taxable intangible.

Each year when the returns are due and are received, or an estimate is mailed out, all five cards can be put into the machine at the same time, and the tops of all five filled out simultaneously. At the same time, columns (d), (e) and $(f)$ on the master, duplicate and alphabetical cards will be completed. Then the cards will be appropriately filed. Periodically as the assessors complete their cards containing the information for the year, columns (b) and (c) will be filled in along with the supporting schedule on the back of the assessor's card and the information transferred to the master file. As the collectors complete their contacts during the year and collections are made, columns (f), (g), (h) and (i) will be completed and copied onto the master file. Thus, at the end of the year, the master file will contain all the information about the taxpayer's transactions during the year, while the collectors and assessors will have a card for each account, each noting the appropriate information on such card. It is also suggested that a manila envelope be prepared for each taxpayer's account, which will. contain all correspondence and returns filed and will be available for ready reference.

Not only will the above system save motion and increase efficiency, but it will also provide a system of internal checks which will make intentional alteration of records more difficult than at present, and will reduce the possibility of mistake arising from the constant recopying presently required. It will also aid in the coordination of the two departments and of the delinquent and current tax divisions within the department today, and will result in better public relations with the taxpayer. 